BULLETIN Bulletin hispanique

HISPANIQUE Université Michel de Montaigne Bordeaux

109-2 | 2007

La formation du Parnasse espagnol $\mathrm{XV}^{\mathrm{e}}-\mathrm{XVIII}{ }^{\mathrm{e}}$ siècle

\title{
La autoridad literaria
}

círculos intelectuales y géneros en la Castilla del siglo XV

\section{Guillermo Serés}

\section{(2) OpenEdition}

\section{Journals}

Edición electrónica

URL: http://journals.openedition.org/bulletinhispanique/209

DOI: 10.4000/bulletinhispanique.209

ISSN: 1775-3821

Editor

Presses universitaires de Bordeaux

\section{Edición impresa}

Fecha de publicación: 1 diciembre 2007

Paginación: 335-383

ISBN: 978-2-85276-096-7

ISSN: 0007-4640

Referencia electrónica

Guillermo Serés, « La autoridad literaria », Bulletin hispanique [En línea], 109-2 | 2007, Publicado el 01 diciembre 2010, consultado el 19 abril 2019. URL : http://journals.openedition.org/

bulletinhispanique/209 ; DOI : 10.4000/bulletinhispanique.209 


\title{
La autoridad literaria: círculos intelectuales y géneros en la Castilla del siglo XV
}

\author{
Guillermo Serés \\ Universidad Autónoma de Barcelona
}

L'évolution des différents cercles intellectuels de la Castille du XVe siècle est analysée en ce qui concerne l'érudition poétique. On constate tout d'abord des différences notables entre les uns et les autres pendant la première moitié du siècle, différences qui s'amenuisent au fur et à mesure que celui-ci avance, pour presque disparaître à partir des années 1460, après la mort de Cartagena, Mena, Santillana ou el Tostado, parallèlement au gain de popularité de la culture classique. Cela entraînera paradoxalement l'abandon progressif de l'arte mayor et d'une poésie trop savante et le retour à une certaine spiritualité, qui trouvera sa meilleure expression dans le conceptisme de Jorge Manrique, de la génération suivante, après les expériences infructueuses de certains poètes de transition tels que Gómez Manrique ou Pero Guillén de Segovia, du cercle de l'archevêque Carrillo. Cette évolution vers une poésie simple et morale sera consacrée, à la fin du siècle, par Juan del Encina.

Se analiza la evolución de los distintos círculos intelectuales de la Castilla del siglo $X V$ en relación con la erudición poética. En primer lugar, se constata cómo durante la primera mitad de siglo hay notables diferencias entre unos y otros, que se van limando conforme avanza el siglo y casi de aparecen a partir de la década de 1460, tras la muerte de Cartagena, Mena, Santillana o el Tostado, y según aumenta la familiaridad con la cultura clasicista. Ello implicará, paradójicamente, que se abandone progresivamente el arte mayor y la poesía demasiado erudita y se vuelva a una cierta espiritualidad, que encontrará su mejor plasmación en el conceptismo de Jorge Manrique, tras los experimentos fallidos de algunos poetas de transición como Gómez Manrique o Pero Guillén de Segovia, del círculo del arzobispo Carrillo. Este cambio hacia la poesía sencilla y moral lo sanciona a final de siglo Juan del Encina.

BHi, Tome 109, n 2 - décembre 2007 - p. 335 à 383. 
The historical development of the different intellectual circles of $15^{\text {th }}$ century Castile are analysed in relation to poetical erudition. First, it is observed that in the first half of the century there were major differences between the different groups, which became smaller as the century went on, and had almost disappeared by the 1460', following the deaths of Cartagena, Mena, Santillana and El Tostado, and as familiarity with classicist culture increased. Paradoxically, this implied the progressive abandonment of 'arte mayor' and excessively erudite poetry, and a return to a certain spirituality, which is best exemplified by Jorge Manrique's 'conceptism' of the next generation, following the failed experiments of some of the poets of the transitional period, such as Gómez Manrique and Pero Guillén of Segovia, in Archbishop Carrillo's circle. This path towards simple, moral poetry was sanctioned at the end of the century by Juan del Encina.

Mots clés : Poésie savante - Arte mayor - Cercles de Salamanque et de Carrillo Premier pétrarquisme - Conceptisme - Poésie morale - Style bas - Juan del Encina.

\section{LOS TRES GRUPOS INTELECTUALES DE LA PRIMERA MITAD DE SIGLO}

Mediado el siglo XV, es posible distinguir, a grandes rasgos, la existencia de tres grupos intelectuales que se dejan caracterizar por su relación con la Antigüedad grecolatina y por la asimilación de los frutos del Humanismo italiano. Entre los miembros del primer círculo se cuentan los intelectuales que aceptaron e intentaron asimilar las novedades derivadas de la moda cultural clasicista y de los incipientes studia humanitatis, pero entendidos fundamentalmente como una actualización erudita de los viejos parámetros de la cultura medieval. Tal es el caso, por ejemplo, de algunos representantes de la alta nobleza, como el marqués de Santillana, cuyo afán por hacerse con las claves culturales y eruditas, que le permitieran, a su vez, asimilar lo que se leía en Italia, le supuso reunir una biblioteca excepcional, bien nutrida de traducciones de los clásicos, a la cabeza de los cuales cita a Virgilio, Séneca, Ovidio o Cicerón ${ }^{1}$, además de «le tre corone» italianas. Mucho le influyó

1. "A ruego e instancia mía, primero que de otro alguno, se han vulgarizado en este reino algunos poetas, así como la Eneida de Virgilio, el Libro mayor de las transformaciones de Ovidio, las Tragedias de Lucio Anio Séneca e muchas otras cosas en que yo me he deleitado fasta este tiempo e me deleito» (Carta a su hijo, Pedro Gónzález de Mendoza; cito por la edición de Ángel Gómez Moreno y M. P. A. M. Kerkhof, Obras completas, Barcelona, Planeta, 1988, pp. 456-457). Cf. la respuesta de don Pedro en mi libro La traducción en Italia y España durante el siglo XV. La "Iliada» en romance y su contexto cultural, Salamanca, Universidad, 1997, pp. 81-91. Sobre la biblioteca del Marqués sigue siendo imprescindible el libro de Mario Schiff, La Bibliothèque du Marquis de Santillane, París, E. Bouillon, 1905 (reimpresión: Amsterdam, G. Th. van Heuden, 1970). 
en su formación Enrique de Villena (le llama «biblioteca de moral cantar»), que le traduce la Commedia de Dante o la Eneida (destinada, en principio, para el rey don Juan de Navarra), o sea, los opera maiora de las dos culturas de referencia. Le llorará don Íñigo en su Defunsión de don Enrique de Villena, comparándolo con los auctores de la Antigüedad y calificándolo como mediador cultural y gestor de la translatio studii antes que él mismo:

\footnotetext{
Perdimos a Homero, que mucho honoraba este sacro monte do nós habitamos; perdimos a Ovidio, al cual coronamos del árbol laureo, que mucho se amaba; perdimos a Horacio, que nos invocaba en todos exordios de su poesía.

Así diminuye la nuestra valía, que en tiempos pasados tanto prosperaba. Perdimos a Livio e al Mantüano, Macrobio, Valerio, Salustio e Magneo; pues non olvidemos al moral Eneo, de quien se laudaba el pueblo romano. Perdimos a Tulio e a Cassilano, Alano, Boecio, Petrarca e Fulgencio; perdimos a Dante, Gaufredo, Terencio, Juvenal, Estacio e Quintilïano ${ }^{2}$.
}

El itinerario de lecturas, desde el cuarteto axial formado por Homero, Virgilio, Ovidio y Horacio («nuestra valía», v. 151) hasta los diecinueve siguientes, es altamente representativo, especialmente por la mezcla de autores antiguos, altomedievales e italianos. Porque la aplicación de dicha cultura clasicista se hace a partir de modelos, géneros, técnicas y objetivos de la tradición medieval. Sin ir más lejos, en el programático Prohemio e carta, para la delimitación de los géneros (comedia, tragedia y sátira) parte de un comentarista de Dante, Benvenuto da Imola, y su concepto cancioneril de poesía, mediatamente provenzal, recuerda el de la Genealogia de Boccaccio, aunque, eso sí, adornado con citas de Cicerón u Horacio, leídos directamente o -lo más probable- espigados, respectivamente, en alguna colección de dichos medievales y en San Agustín ${ }^{3}$. Al lado de Santillana, o a su zaga, autores como Juan de Mena, Pedro Díaz de Toledo, Pedro de Portugal, Nuño

2. Cito por la edición de Regula Rohland de Langbehn, Comedieta de Ponza, sonetos, serranillas y otras obras, Barcelona, Crítica, 1997, pp. 130-131.

3. Lo ilustra muy bien Domingo Ynduráin, Humanismo y Renacimiento en España, Madrid, Cátedra, 1994; complétese con Brian Tate, «El humanismo en Andalucía en el siglo XV», eds. C. Terán Sánchez et al., Andalucía 1492: razones de un protagonismo, Sevilla, Algaida, 1992, pp. 213-241, 218-227. 
de Guzmán y varios poetas cancioneriles que, deslumbrados por las obras redescubiertas, irán redactando, encargando o leyendo nuevas traducciones e intentarán aclimatar y adecuar los prestigiosos géneros, autores o saberes de la Antigüedad a las técnicas, conceptos o códigos heredados ${ }^{4}$. Una difícil empresa, pero no infructuosa, pues gracias a la curiosidad y el esfuerzo de estos intelectuales por alcanzar las novedades importadas de Italia se fueron creando las condiciones para la llegada del Humanismo, sin que al parecer pesase demasiado en la elección el fundamento moral de los auctores ${ }^{5}$. Buena prueba de ello es la obra misma de los citados, graves y menos graves, como las aventuras y amores de las pudorosas heroínas ovidianas, la ampulosa mitología del Séneca trágico, los milites caballerescos de Valerio Máximo, los misterios de Virgilio o la nigromancia de Lucano.

Otro sector intelectual, el segundo, estaba formado por escritores que se acercaron a la cultura antigua con asepsia profesional y la aplicaron con indiferencia o neutralidad, con la distancia de glosadores o explanadores, combinándola con la de las auctoritates medievales, ajustándola a sus cauces formales o genéricos, adecuándola a los modi legendi de la Escolástica ${ }^{6}$. Así, aunque se puedan observar resonancias clasicistas en Los doze trabajos de Hércules, de Enrique de Villena, sigue siendo un dechado de exégesis medieval; aunque traduzca la Eneida, la moraliza "científicamente», cumpliendo el encargo de romancear a Virgilio y de difundir dichas materias y obras entre los cavalleros, pero para que, fundamentalmente, sirvieran como manual de regimiento de príncipes y como listas o galerías de exempla de la Antigüedad ${ }^{7}$. Análogamente, cuando Juan Rodríguez del Padrón,

4. Véanse, por ejemplo, Francisco Crosas, La materia clásica en la poesía de cancionero, Kassel, Reichenberger, 1995; específicamente, $\mathrm{M}^{\mathrm{a}}$ Isabel López Bascuñana, «El mundo y la cultura grecorromana en la obra del marqués de Santillana», Revista de Archivos, Bibliotecas y Museos, LXXX (1977), pp. 271-320.

5. Aparte el conocido estudio El Humanismo castellano del siglo XV, Valencia, Fernando Torres, 1976, véanse los otros trabajos que a este motivo ha dedicado Ottavio Di Camillo, "Humanism in Spain», en Renaissance Humanism. Foundations, Forms and Legacy, Filadelfia, University of Pennsylvania Press, 1988, II, pp. 55-108; «Interpretations of the Renaissance in Spanish Historical Thought», Renaissance Quarterly, XLVIII (1995), pp. 352-365; "Interpretations of the Renaissance in Spanish Historical Thought: The Last Thirty Years», Renaissance Quarterly, XLIX (1996), pp. 360-383; «Interpretations of Humanism in Recent Spanish Renaissance Studies», Renaissance Quarterly, L (1997), pp. 1190-1201.

6. Véanse Louis Holtz, "Glosse e commenti», en Lo spazio letterario del Medioevo. 1. Il Medioevo Latino, III: La ricezione del testo, eds. G. Cavallo, C. Leornari y E. Menestò, Roma, Salerno, 1995, pp. 59-111; Jesús Rodríguez Velasco, «La Biblioteca y los márgenes. Ensayo teórico sobre la glosa en el ámbito cortesano del siglo XV en Castilla. I: códice, dialéctica y autoridad", eHumanista. Journal of Iberian Studies, 1 (2001), pp. 119-134.

7. Pedro M., Cátedra, ed., Enrique de Villena, Traducción y glosas a la "Eneida». (Libros 
por ejemplo, traduce, en su Bursario, las Heroidas tiene a la vista, e incluso imita, la versión alfonsí de la obra ovidiana parcialmente incorporada a la General estoria e incluso algún Ovidio moralizado medieval con que glosar interlinealmente el texto ${ }^{8}$; cuando redacta el Planto de la Pantasilea, intenta remedar las elegías ovidianas con el planctus medieval, el amor ovidiano con el fino amor; análogamente, en el Siervo libre de amor, encauza la salus en la altercatio escolástica.

Conforme avance el siglo, no van a ser pocos los autores traducidos, total o parcialmente, a las lenguas vernáculas, para uso, principalmente, de los aristócratas legos ${ }^{9}$. Una avalancha de determinado tipo de auctoritates al alcance de los amateurs que alarmó a algunos intelectuales, de diversa formación: los integrantes del tercer grupo, que intuyeron, unos, o fueron realmente conscientes, otros, del peligro que entrañaba la lectura y posible asimilación de estas obras, en tanto que ciertos valores o ideales que rezumaban se oponían frontalmente a los tradicionales parámetros culturales, doctrinales o morales. El rechazo de una parte de este larvado humanismo se aprecia eventualmente en Alfonso de Cartagena y en Rodrigo Sánchez de Arévalo, Juan Femández de Híjar, los dos Carvajales, en una parte de la obra de Pérez de Guzmán y en tantos otros. No sólo recelan de la moralidad de algunas lecturas, sino también de la consideración de la elocuencia como un valor en sí misma, como podemos comprobar en este poema de Pérez de Guzmán, cuyo significativo epígrafe reza "Como no está el seso en mucho fablar nin aun en bien fablar»:

Si el seso estuviese en mucho fablar, los tordos serían discretos llamados;

I-III), 3 vols., Salamanca, Biblioteca Española del Siglo XV-Diputación Provincial, 19891990; Sol Miguel-Prendes, «Translation, Authority, and Authorship in the Works of Enrique de Villena and Juan de Mena: The Emergence of the Vernacular Author in Fifteenth-Century Castile», Allegorica, 6 (1996), pp. 17-33; Idem, El espejo y el piélago. La "Eneida» castellana de Enrique de Villena, Kassel, Reichenberger, 1998. Cf. Alberto Blecua, «Virgilio en España en los siglos XVI y XVII", en Actes del VI Simposi d'Estudis Clàssics, Bellaterra, Secció Catalana de la Societat Espanyola d'Estudis Clàssics-Universidad Autónoma de Barcelona, 1985, pp. 61-77.

8. Cf. los excelentes trabajos de Ma Rosa Lida, "La General estoria: notas literarias y filológicas», Romance Philology, XII (1958-59), pp. 111-142; XIII (1959-60), pp. 1-30; complétese con Olga T. Impey, «Ovid, Alfonso X, and Juan Rodríguez del Padrón: Two Castilian Translations of the Heroidas and the Beginings of Spanish Sentimental Prose», Bulletin of Hispanic Studies, LVII (1980), pp. 283-297.

9. Tito Livio, César, Quinto Curcio, Josefo, Justino, Valerio Máximo, Paulo Orosio, los dos Plinios, Plutarco, Procopio, Salustio, Vegecio, Frontino, Polibio, Eutropio, Tucídides, Homero (y la Ilias Latina), Lucano, Virgilio, Ovidio, Cicerón, Luciano, Paladio, Séneca, Platón, Aristóteles, etc., etc. 
nin está, digo, en bien razonar, que muchos livianos vi bien razonados.

Non dixo el apóstol sed bien fabladores, seguid la teórica de Quintilïano, mas dixo: «carisisimo, estote factores, non imitadores, que es acto liviano". Mejor es ser Cato que virgiliano: la vida de uno nos edeficó, mas el deleitable que fructificó [fue] el fermoso estilo del grant mantüano ${ }^{10}$.

Y dedicado, precisamente, a Pérez de Guzmán (en el tardío 1454), baste ver el Oracional de Cartagena, donde desaprueba «aquel estillo antiguo, gentil e pagano... que fizieron los griegos e aun los romanos ante que la santa fee recibiesen». Un poco antes, viendo algunos fabulosos libros que una parte de los caballeros leía, las licenciosas traducciones que elegían algunos curiales, e incluso de los clérigos, salió a la palestra para criticar las lecturas peligrosas, dirigidas a la imaginación de receptores moral e intelectualmente inermes:

A libris itaque illis abstinendum erit, qui ad inhonestatem videntur allicere, uti sunt amatoria, bucolica, aliaque poetarum figmenta, que, licet eloquenti stilo et acuta inventione composita sint, magnamque ingenii elevationem ostentent, cum mirabili compositione metrorum exquisitisque verbis coagulata dulcem saporem conficiant, in nonnullis tamen eorum materia obscena et provocativa libidinum est ${ }^{11}$.

Para los «militaribus viris», aficionados a las letras, lo más indicado son las crónicas, sobrias, útiles, verdaderas y dirigidas a la memoria y al entendimiento, no a la imaginación ${ }^{12}$ :

10. Ma Jesús Díez Garretas y Ma Wenceslada de Diego Lobejón, Un cancionero para Álvar García de Santamaría. "Diversas virtudes y vicios» de Fernán Pérez de Guzmán, Tordesillas, Universidad de Valladolid, 2000, p. 142.

11. Lo edita J. N. H. Lawrance, Un tratado de Alonso de Cartagena sobre la educación y los estudios literarios, Universidad Autónoma de Barcelona, Bellaterra, 1979, p. 50, cursiva mía. Cf. Luis Fernández Gallardo, «Tradición clásica, política y humanismo en la Castilla del Cuatrocientos. Las glosas de Alonso de Cartagena a De providentia», Anuario de Estudios Medievales, 24 (1994), pp. 967-1002; Andrea Baldissera, ed., Alonso de Cartagena, Pro Marcelo, Lucca, Agua y Peña, 2003.

12. Pues es la potencia interior que deben cultivar especialmente, "ca entendimiento es la cosa que más enderesça al omne para ser complido en sus fechos... e por ende, los caballeros que han a defender a sí e a los otros, segund que dicho habemos, deben ser entendidos» (José María Viña Liste, ed., Alonso de Cartagena, Doctrinal de los caballeros, Santiago de 


\section{LA AUTORIDAD LITERARIA}

cronice... perutiles sunt ille tamen que vera, non que ficte composita narrant. Nam cum omnia ad dirigendos mores nostros reducenda sint, nonne ridiculum et in fictis et falso compositis soliditatem morum fundare? Ut veraciter ergo vivamus, vera semper iaciamus cementa. Etenim que ficta sunt nedum ex ipsa falsitate reiicienda fore existimo... Sicuti sunt Tristani ac Lanceloti Amadisiive ingentia volumina, que absque aliqua edificationis spe animos legentium oblectant... Huiusce modi enim scripture, etsi nocive nimium sint, infructuose tamen et nullius utilitatis esse videntur. (pp. 53-54)

También porque las crónicas ofrecen modelos reales que pueden ser imitados por los milites sin formación, demasiado a menudo atraídos por Tristanes, Lanzarotes o Amadises. Cada uno actúe y lea según su estamento y formación -parece deducirse de las palabras del obispo de Burgos-: los scholastici viri (entre los que se cuenta) y los del medium genus, entre los que se cuentan los militares viri. Para éstos, ninguna verdad y ninguna utilidad podrá extraerse de aquellos poetarum figmenta; incluso cree que el Cantar de los cantares plantea graves problemas a los lectores menos formados ${ }^{13}$.

La actitud de este grupo se remonta más de medio siglo a don Pero López de Ayala (1332-1407), por lo menos, que en 1386 tradujo (aunque de la versión francesa de Pierre Berçuire) las Décadas de Tito Livio, aunque también la encontraremos eventualmente en el último Juan de Mena y el Tostado, Fernando del Pulgar, Juan de Lucena o Alfonso Ortiz. El citado López de Ayala dará una impronta fundamental al afirmar que las Décadas de Livio -historia al fin y al cabo- por él traducidas y comentadas merecen divulgarse para que

los príncipes e los cavalleros que [las] oyeren tomen buen exenplo e buena esperençia e esfuerço en sí catando cuánto provecho e cuánta onra nace de la buena ordenança e de la buena desceplina de cavallería e de la buena obedencia en las batallas, e cuánto estorvo e daño e peligro viene al contrario ${ }^{14}$.

Compostela, Universidad, 1995, p. 26); no hay ningún epígrafe en que se recomiende la lectura y, por lo tanto, la imaginación.

13. Pues considera Cartagena que, según la exposición de Orígenes, «hic tamen in expositionibus sue exordio narrat libri illius antiquis in seculis adolescentibus ac iuvenibus lectionem fuisse prohibitam, quia unionem anime rationalis ad Deum sub tipo carnalis amplexus scribit et caritatis ardorem adhesionisque desiderium... sub imagine sponsalicii amoris designat» (p. 52). Véase ahora la excelente tesis doctoral inédita de Sergio Fernández López, Lecturas hebraizantes del "Cantar de los cantares» en la literatura española. De la Edad Media al Humanismo, Universidad de Huelva, 2007, pp. 128-141 y passim.

14. Cito por la edición de Curt J. Wittlin, ed., Pero López de Ayala, Las Décadas de Tito Livio. Edición crítica de los libros I-III. Barcelona, Puvill, 1982, 2 vols. 
Así, además de la novedad y del gusto de leer 'historias de romanos', el caballero que se acerque a la obra de Livio obtendrá ejemplos de ordenança y desceplina, virtudes siempre asociadas al concepto de caballería; y por si fuera poco, dichas historia fueron leídas como documentos de regimine principum o manuales del arte militar que pudiera aplicarse al presente ${ }^{15}$. Semejantes propósitos cumplen las traducciones de Frontino, Vegecio, Solino, Justino, Valerio Máximo.... Pero éstos, los cavalleros, necesitaban acercarse a los textos con la ordinatio previa de los intérpretes y maestros, que solían ser dictadores, curiales e intelectuales profesionales, de cualquiera de los tres grupos citados. Es decir, que, para estos intelectuales, la interpretación y comentario del texto depende en gran medida del lector al que va dirigida la traducción. Un ejemplo claro es, de nuevo, Cartagena: cuando escribe o traduce para los magnates (por ejemplo, la Cuestión a Santillana ${ }^{16}$ ), encauza y orienta moralmente la oratio o la traducción ${ }^{17}$; cuando, en cambio, se cartea o entrevista con sus 'iguales', italianos o españoles ${ }^{18}$, ejerce, en lo que cabe, de humanista ${ }^{19}$.

15. Lo recuerda explícitamente Pérez de Guzmán: «Sciencia y caballería, / cuanto a la mundana gloria,/ esclarecen la memoria / con singular nombradía;/ esta noble compañía es muy grave de juntar,/ pero junta, no ha par / nin precio su gran valía» (Un cancionero para Álvar García de Santamaría, p. 221).

16. Véase Ángel Gómez Moreno, «La Qüestión del marqués de Santillana a don Alfonso de Cartagena», El Crotalón, II (1985), pp. 335-363.

17. Nicholas G. Round, «'Perdóneme Séneca’. The Translational Practices of Alonso de Cartagena», Bulletin of Hispanic Studies [Glasgow], LXXV (1998), pp. 17-29.

18. A Cartagena precisamente hay que hacer en gran medida responsable del inicio de las relaciones culturales entre los humanistas italianos y la corona de Castilla. Más frecuente fue el contacto de Rodrigo Sánchez de Arévalo con Pío II, Pablo II, Pomponio Leto, Bessarion y otros.

19. Cf. Olga T. Impey, «Alfonso de Cartagena, traductor de Séneca y precursor del humanismo español», Prohemio, III (1972), pp. 473-494; María Morrás, «Sic et non. En torno a Alfonso de Cartagena y los studia humanitatis», Evphrosyne, XXIII (1995), pp. 333346; Idem, ed., Alonso de Cartagena, Libros de Tulio: "De senetute», "De los ofiçios», Alcalá de Henares, Universidad, 1996; Idem, "Una cuestión disputada: viejas y nuevas formas en el siglo XV. A propósito de un opúsculo inédito de Rodrigo Sánchez de Arévalo y Alfonso de Cartagena», Atalaya, VII (1996), pp. 63-102; Idem, "El debate entre Leonardo Bruni y Alonso de Cartagena: las razones de una polémica», Quaderns. Revista de Traducció, VII (2002), pp. 33-57. En general, Ángel Gómez Moreno, España y la Italia de los humanistas. Primeros ecos, Madrid, Gredos, 1994. 


\section{EL CÍRCULO DE SALAMANCA Y EL RELEVO GENERACIONAL}

Con todo, el tercero no es un grupo uniforme, pues a los López de Ayala o Cartagena sucedieron otras generaciones de traductores y guías que fueron interpretando, con mayor vecindad con el humanismo, lo más florido de la literatura clásica o los escritos de los humanistas italianos; sirva citar, respectivamente, la traducción de Pero Díaz de Toledo de la versión latina de algún diálogo platónico ${ }^{20}$, o la de Vasco Fernández de Lucena del De moribus ingenuis et liberalibus studiis, de Pier Paolo Vergerio, para don Pedro de Portugal. También de Díaz de Toledo, la Homilia XXII (De libris gentilium legendis) de San Basilio ${ }^{21}$, cuya versión latina, preparada por Leonardo Bruni, llegó a erigirse en manifiesto a favor de la lectura de los clásicos (aunque siempre según un estricto criterio de moralidad) y en defensa de la poesía y la elocuencia ${ }^{22}$; dedicada a Santillana, le sirvió como argumento con que enfrentarse a «aquellos que quieren obtrectar ['denigrar'] los estudios de la humanidat». Esta posición, con todas las salvedades que se quieran, va a generalizarse conforme avance el siglo, pues irán evolucionando las actitudes y la consecuente valoración de los clásicos. Juan de Mena (1411-1454) y Alfonso de Madrigal, el Tostado (ca. 1410-1455), los dos curiales, tomarán el relevo del miembro más notorio del tercer grupo y del alto clero, Cartagena, cada vez menos tolerante con la cultura clasicista, o del representante del segundo grupo y de la nobleza, Villena; del primero seguirá, señero, Santillana. Establecerán en la Salamanca de mitad de siglo un círculo intelectual más uniforme del que se sentirán partícipes personajes de muy diverso origen y formación, e incluso de diferentes generaciones: el mismo Juan II (1406-1454), Pérez de Guzmán (ca. 1378-ca. 1460), el propio Santillana (1398-1458), Nuño de Guzmán (¿1410?-¿1475?), Diego de Valera (1412-después de 1488), Diego de Burgos (muerto después de 1458), Gómez Manrique (1413-1491), Fernando de la Torre (ca. 14161475), Alonso de Palencia (1423-1492), o Pedro de Portugal (ca. 14291466).

20. Cf. Nicholas G. Round, «The Shadow of a Philosopher: Medieval Castilian Image of Plato», Journal of Hispanic Philology, III (1978), pp. 187-227; Idem, Libro llamado «Fedrón». Plato's "Phaedro" Translated by Pero Díaz de Toledo, Londres-Madrid, Tamesis, 1993.

21. Cf. Jeremy N. H. Lawrance, «La traduction espagnole du De libris gentilium legendis de Saint Basile, dédiée au Marquis de Santillane», Atalaya, I (1991), pp. 81-115.

22. Cf. P. Viti, "Leonardo Bruni e le polemiche antiumanistiche», en Gli umanesimi medievali. Atti del II Congresso dell' «Internationales Mittelalteinerkomitee», ed. C. Leonardi, Florencia, Universidad, 1998, pp. 795-805. 
Aquella progresiva, aunque no uniforme, aceptación de la cultura clasicista, por otra parte, comportará la extinción de los tres grupos citados, cuya existencia diferenciada no va más allá del medio siglo, pues ni Mena ni Santillana ni Cartagena ni el Tostado traspasan la década de los cincuenta. El 'relevo' generacional, así, tendrá lugar durante este decenio, pues en 1454 mueren Mena y Juan II; en 1455, el Tostado; en 1458, Santillana; por esas mismas fechas, en 1456, Cartagena. Alonso de Palencia ocupará el cargo de secretario de letras latinas que ocupaba Mena y compondrá, ya bajo Enrique IV, una elegía al Tostado ${ }^{23}$, cerrando simbólicamente una época y abriendo otra que se prolongará hasta la llegada del Humanismo propiamente dicho («Humanismo isabelino», en palabras de Eugenio Asensio), o sea, hasta Nebrija, que llega de Italia en 1470 para desterrar la barbarie de la Universidad y que publica, en 1481, sus Introductiones Latinae ${ }^{24}$.

De modo que la división en tres grupos intelectuales se circunscribe a la primera 'generación' -y las fronteras entre ellos no son infranqueables, como ilustra el propio Mena-; las siguientes irán asimilando progresiva y más parejamente el contenido real de las obras clásicas para otras tantas utilidades y adecuando los géneros recuperados por los humanistas italianos. De modo que, a la primera, que cierra el Tostado y que se podría completar con los poetas de transición Gómez Manrique (1412-1490) y Pero Guillén de Segovia (¿1413-1480?), sucede la de quienes alcanzan la época de Enrique IV y, aunque no todos, la de los Reyes Católicos, cuya figura más característica es Jorge Manrique (1440-1479). Me refiero a escritores como el citado Alonso de Palencia (1423-1492), Diego Rodríguez de Almela (¿1426?-1491/492), Fernando del Pulgar (1420/1430-antes de 1500), Juan de Lucena (ca. 1430-¿1506?), etc.; sin olvidarnos de la labor de nobles como don Carlos, príncipe de Viana (1421-1462) y traductor de Aristóteles, o del mecenazgo del cardenal Mendoza (1428-1495), hijo de Santillana. También caben en la lista personajes que, aun siendo de la

23. Robert B., Tate, "The Civic Humanism of Alfonso de Palencia», Renaissance and Modern Studies, XXIII (1979), pp. 25-44; Idem, "Alfonso de Palencia y los preceptos de la historiografía", en Nebrija y la Introducción del Renacimiento en España. Actas de la III Academia Literaria Renacentista, ed. V. García de la Concha, Salamanca, Universidad, 1983. pp. 37-51. Sobre el Tostado, véase ahora Carmen Parrilla, «'Qui scit, docere debet'. Acerca de Alfonso de Madrigal el Tostado", Archivum, LIV-LV (2004-2005), pp. 367-390.

24. Verdadero arranque del Humanismo en sentido estricto, como ha demostrado Francisco Rico, Nebrija frente a los bárbaros, Salamanca, Universidad, 1978; Idem, "Un prólogo al Renacimiento español. La dedicatoria de Nebrija en las Introductiones Latinae (1488)", en Seis lecciones sobre la España de los Siglos de Oro. Homenaje a M. Bataillon, eds. P. Piñero et al, Sevilla, Universidad, 1981, pp. 59-94. En general, Giuseppe Billanovich, Auctorista, humanista, orator, Bellaterra, Universidad Autónoma de Barcelona, 1989. 
generación de Nebrija (1441/1444-1522), están más cerca, culturalmente hablando, de la de Palencia; tal es el caso de Alfonso Ortiz (ca. 1445-después de 1491) o de Diego de San Pedro (después de 1450-después de 1498), o la del tardío Pedro de Cartagena (1456-1486). Son escritores mucho más familiarizados con las obras clásicas que sus deslumbrados predecesores (de los que se consideran discípulos), que se caracterizan, como veremos, por el abandono casi total del arte mayor (baste ver las Coplas, de Jorge Manrique), por la moderación en el uso de lo más llamativo del legado antiguo y por la progresiva asimilación del contenido real del humanismo italiano.

\section{NueVOS GÉNEROS EN PROSA Y LA EVOLUCIÓN DE LA POESÍA}

La paulatina familiaridad con la cultura clasicista implica que exterioricen mucho menos su pretendida apropiación. Se comprueba en el cultivo de ciertos géneros -epistulae, orationes y algún que otro dialogus- que demuestran la más que mediana asimilación de los géneros, modelos fines del humanismo ${ }^{25}$. $\mathrm{Si}$, por ejemplo, tomamos el género epistolar, es fácil comprobar cómo aquellos diletantes de la segunda mitad de siglo van adaptando lentamente el estilo y el decorum ciceroniano o senequista, ya sea por haberlo aprendido directamente de los modelos clásicos, ya de los peninsulares (por ejemplo, de Diego de Valera); pero alejándose progresivamente de la plantilla del ars dictandi ${ }^{26}$. Pulgar incluso es capaz de discernir los tres géneros ciceronianos: la carta de noticias, el genus familiare et iocosum y el genus severum et grave ${ }^{27}$, y en su Letra XXI da cuenta, para justificar el género familiar, de que vio a Santillana, Fernán Pérez de Guzmán
y a otros notables varones escrebir mensajeras de mucha dotrina interponiendo en ellas algunas cosas de burlas que daban sal a las veras. Leed, si os place, las epístolas de Tulio... y fallaréis interpuestas asaz burlas en las veras ${ }^{28}$.

25. Todo ello, claro, a excepción de la más tardía imitación de la comoedia terenciana (o de la commedia umanistica) que redactó el ya discípulo de Nebrija y autor de la Comedia de Calisto y Melibea (antes de 1496), donde supera la definición medieval del género.

26. Cf. Ronald G. Witt, «Medieval ars dictaminis and the Beginnings of Humanism: A new Construction of the Problem», Renaissance Quarterly, XXXV (1982), pp. 1-35.

27. Jeremy N. H. Lawrance, «Nuevos lectores y nuevos géneros: apuntes y observaciones sobre la epistolografía en el primer renacimiento español», en Literatura en la época del Emperador. Academia Literaria Renacentista V, ed. V. García de la Concha, Salamanca, Universidad, 1988, pp. 81-99. Cf. Gonzalo Pontón, Correspondencias. Los origenes del arte epistolar en España, Madrid, Biblioteca Nueva, 2002.

28. Paola Elia, ed., Fernando del Pulgar, Letras, Pisa, Giardini, 1982, p. 80. 
Se siente respaldado por una tradición epistolográfica, de la que son buenos y correlativos ejemplos el Libro de las veinte cartas e qüistiones (ca. 1455) de Fernando de la Torre, donde rechaza abiertamente la «retórica frairiega» $(X X V I I I)^{29}$; el epistolario de Alonso de Palencia (a partir de la década de los sesenta ${ }^{30}$ ); o la epístola exhortatoria a las letras, de Juan de Lucena (ca. 1492) ${ }^{31}$. Otro tanto cabría decir, por ejemplo, del desarrollo del género historiográfico, sin el que no se explican los Claros varones de Castilla (impreso en 1486), de Pulgar, mucho más cerca de los modelos clásicos que las Generaciones y semblanzas (1450 y 1455), de Pérez de Guzmán ${ }^{32}$. Por no hablar del dialogus, que permitirá a Juan de Lucena escribir, más o menos canónicamente, el De vita beata (1463), aunque también tenía el precedente español del Diálogo e razonamiento, de Díaz de Toledo, ya muy alejado de las altercationes medievales.

Conforme avance el siglo, la poesía, como anunciaba, se irá alejando progresivamente del impostado arte mayor (que se seguirá cultivando hasta mediado el siglo XVI) y del estilo latinizante que presidió la generación del medio siglo, pues la de Jorge Manrique dispondrá de una lengua ya formada ${ }^{33}$. La ostentación erudita irá dejando paso a las citas y alusiones mucho menos explícitas, y la aparente paganización irá cediendo el sitio a una progresiva espiritualidad y a un cultivo mucho mayor de la poesía grave, moral o política; a una especie de ascetismo que buscase «conciliar cristianismo y humanismo» ${ }^{34}$. Vuelven a las fuentes de la generación

29. Cf. Ma Jesús Díez Garretas, ed., La obra literaria de Fernando de la Torre, Valladolid, Universidad, 1983.

30. Robert B. Tate y R. Alemany, ed., Alfonso de Palencia, Epistolas latinas, Bellaterra, Universidad Autónoma de Barcelona, 1982, pp. 7-25.

31. Véase Lucia Binotti, "La Epístola exhortatoria a las letras de Juan de Lucena. Humanismo y educación en la Castilla del siglo XV», La Corónica, XXVIII (2000), pp. 51-80; complétese con Juan Carlos Conde, «El siglo XV castellano a la luz del Diálogo de vita beata de Juan de Lucena», Dicenda, IV (1985), pp. 11-34; Guido Cappelli, El humanismo romance de Juan de Lucena. Estudios sobre el «De vita felici», Bellaterra, Universidad Autónoma de Barcelona, 2002; Olga Perotti, ed., Juan de Lucena, De vita felici, Pavia, Ibis, 2004.

32. Véase simplemente Robert B. Tate, "Alfonso de Palencia y los preceptos de la historiografía", en Nebrija y la introducción, pp. 37-51; Robert Folger, "Generaciones y semblanzas": Memory and Genealogy in Medieval Iberian Historiography. Romanica Monacensia 68. Tübingen: Gunter Narr, 2003; en general, Mariangela Regoliosi, «Riflessioni umanistiche sullo scrivere storia», Rinascimento, XXXI (1991), pp. 3-37.

33. M. Menéndez Pelayo, Antología de poetas lyricos castellanos, Madrid, CSIC, 1944, p. 410. En general, Pierre Le Gentil, La Poésie lyrique espagnole et portugaise à la fin du Moyen Age, I, Les Thèmes et les genres, Rennes, Philon, 1949.

34. María Morrás, ed., Jorge Manrique, Poesía, Madrid, Castalia, 2003, p. 24; más abajo apunta que «se busca en el neoplatonismo una perspectiva para hacer concordar filosofía y 
precedente a la primera, lo que Rico llama una rebelión en alianza «con los abuelos contra los padres» ${ }^{35}$, para reencontrarse con los eximios representante de la Patrística y San Pablo, con Séneca y Cicerón de nuevo, con el cristocentrismo de la religiosidad franciscana, que se reconoce en los Manrique. Jorge, por ejemplo, nos presenta a su padre como un catálogo de cualidades, al decir de Pedro Salinas, que se traduce en la síntesis de la virtus clásica y la fe cristiana, o sea, en un compendio de los valores de Ética aristotélica y las virtudes cardinales y teologales del cristianismo ${ }^{36}$.

Las dos generaciones, con todo, fueran cuales fueran las actitudes, se articularán en torno a Santillana: Villena, el Tostado y otros le traducen y explanan textos latinos; Imperial le trae un remedo del modelo dantesco, formal y alegóricamente, que él perfeccionará; Cartagena le aconseja y traduce obras morales y retóricas; Mena continuará y perfeccionará los «decires» en arte mayor; Nuño de Guzmán (entre muchos otros) le sirve libros y le relaciona con los humanistas italianos; Pedro de Portugal y Fernán Pérez de Guzmán, sus «iguales», también forman parte de su círculo; Pero Guillén de Segovia y Gómez Manrique se postularán como sucesores y, en fin, Jorge Manrique le emulará, y es quien, curiosamente, conducirá la renovación poética, más vinculada al petrarquismo (véase abajo). Hacia el Marqués convergen y de él dependen los afanes de la mayor parte de la intelectualidad "prehumanista». Por eso mismo, alrededor de 1460, en el prefacio a su Triunfo del marqués, Diego de Burgos, familiar suyo, insistía en la idea de auctoritas, con la consecuente translatio studii, que, según él, encarnó como nadie de su tiempo don Íñigo López de Mendoza, digno sucesor de sus «compatriotas» Lucano, Séneca o Quintiliano:

\footnotetext{
como el varón de alto ingenio viese por discursos de tiempos, desde Lucano e Séneca e Quintiliano e otros antiguos e sabios, robada e desierta su patria de tanta riqueza, doliéndose dello, trabajó con grand diligencia por sus propios estudios e destreza, e con muchas e muy claras obras compuestas dél mesmo, igualarla e compararla con la gloria de los famosos hombres de Atenas o de Academia, e también
}

cristianismo" (p. 25).

35. Francisco Rico, "La tradición, el poema», en Breve biblioteca de autores españoles, Barcelona, Seix Barral, 1990, pp. 286-293, 293.

36. «Virtù come la prudenza, la bontà, la liberalità, la fortezza, la clemenza, ecc., son tali che non conoscono una istituzionalità ed una chiusura morale se, per pagane che siano, attribuite come sono a grandi personaggi del mondo clásico, risplendono di una luce sovranamente cristiana» (Gualterio Cangiotti, Le "Coplas» di Manrique tra Medioevo e Umanesimo, Riccardo Pàtron, Bolonia, 1964, p. 95); más abajo apostilla que «in ultimo, l'ars vivendi di Don Rodrigo è fatta della pratica stessa delle virtù cristiane ed umanistiche delle quali il poetea vede in lui la personificazione più schietta» (p. 99). 


\section{BULLETIN HISPANIQUE}

de romanos, trayendo a ella grand copia de libros de todo género de filosofía en estas partes fasta entonce non conoscidos, enseñando él por sí a muchos e teniendo hombres muy sabios que a la letura de otros aprovechasen; después desto, mostrando e declarando el seso e las moralidades que las poéticas ficiones en sus fablas tienen veladas, dando a conocer el fruto que de la sabia elocuencia se puede seguir, argumentando la delectación que se toma de las grandes e pelegrinas estorias por las quales los ánimos generosos a grandes fazañas e virtudes son incitados, e no menos trayendo a memoria el proveimiento que dellas se debe tomar para los infortunos casos humanos, e dando en toda dotrina orden de documentos a todo estado de hombres para facerse muy enseñados. Así que ya por su causa nuestra España resplandece de ciencia... Pues si Apolonio así se dolía que de los griegos por industria de Tulio la elocuencia fuese a los romanos levada, cuánto más con razón hoy los de Italia se deben doler e quejar que por lumbre y ingenio deste señor a ellos sea quitada e traída a nuestra Castilla e ya en ella a tanta gloria floresca, que notoriamente se vean sobrados ${ }^{37}$.

Diego de Burgos destacaba especialmente la autoridad exegética o hermenéutica del Marqués, que descifró el «seso e las moralidades» que velan las "poéticas ficiones», o sea, la "fermosa cobertura» de la que habla en su Prohemio e carta (véase abajo). A continuación subrayaba que hizo trasladar las historias ejemplares, "grandes e pelegrinas», para que los «cavalleros» de su tiempo las leyesen e imitasen ${ }^{38}$, o para que escarmentasen con los casus virorum illustrium de la Antigüedad, considerada como galería de ejemplos ${ }^{39}$. También encargó o redactó, sendas ordinationes de los consejos («documentos») de «toda dotrina», para cualquier «estado de hombres»,

37. Lo publicó Mario Schiff, La Bibliothèque du Marquis de Santillane, pp. 460-464, esp. 461-462; la noción de translatio la estudia Francisco Rico, "Aristóteles Hispanus: en torno a Gil de Zamora, Petrarca y Juan de Mena», Italia Medioevale e Umanistica, X (1967), pp. 143-164; reeditado en Textos y contextos. Estudios sobre la poesía española del siglo XV, Barcelona, Crítica, 1990, pp. 55-94.

38. Cf. Ángel Gómez Moreno, «La militia clásica y la caballería medieval: las lecturas de re militari entre Medioevo y Renacimiento", Evphrosyne, XXIII (1995), pp. 83-97; Idem, ed., Sexto Julio Frontino, Los cuatro libros de los Enxemplos, consejos e avisos de la guerra (Strategematon), Madrid, Ministerio de Defensa, 2005; complétese con Jesús Rodríguez Velasco, El debate sobre la caballería en el siglo XV, Salamanca, Junta de Castilla y León, 1996.

39. No es otra la función de la tragedia, como señala el mismo marqués en la carta a doña Violante de Prades, donde equipara las de Séneca con el De casibus virorum illustrium de Boccaccio, pues en ambos casos se cuentan casos de hérores «cuyos nascimientos e vidas alegremente se començaron e grande tienpo se continuaron e después tristemente cayeron. E de fablar destos usó Séneca... en las sus tragedias e Iohan Bocacio en el libro De casibus virorum illustrium» (ed. cit., pp. 435-437, 436). 
como son, por ejemplo, los Proverbios. Por él, en fin, nos tiene envidia Italia. Y, por supuesto, dio la pauta para toda la poesía culta posterior, como se demuestra en la misma invocación de la Comedieta de Ponza (1435-36), uno de los poemas más admirados de su tiempo:

$$
\begin{aligned}
& \text { ¡O lucido Jove, la mi mano guía, } \\
& \text { despierta el ingenio, aviva la mente, } \\
& \text { el rústico modo aparta e desvía } \\
& \text { e torna mi lengua, de ruda, elocuente! }
\end{aligned}
$$

Pauta incluso, dicho sea de paso, de las diametralmente opuestas Coplas de Manrique, que usa los mismos verbos del verso 10 en el arranque del poema: «Recuerde el alma dormida,/ avive el seso y despierte». Consecuente con la translatio, el título de la obra de Diego de Burgos vincula a Santillana con la más brillante poesía anterior: los homónimos «trionfi» de Petrarca, de quien incorpora muchos elementos, incluida la descripción de la Muerte que visita a Laura:

$$
\begin{aligned}
& \text { Y vi la que antes dubdosa tenía } \\
& \text { mostrar ya su forma humana de cierto, } \\
& \text { la cual un gran manto de negro traía }{ }^{40} \text {. }
\end{aligned}
$$

$\mathrm{Al}$ poco, desaparece el Marqués y se incorpora Dante, que le guía por el infierno hasta el purgatorio, donde contemplan a los personajes que confían llegar al paraíso, armados por la «ínclita fama», que les permitirá triunfar sobre la muerte. Son los mismos que ve Petrarca en el tercer triunfo, y los cita por sus virtudes militares y literarias: entre éstos, Villena, Alonso de Cartagena, Juan de Mena y el Tostado. Todos pronuncian sendas laudes del Marqués, que habla en último lugar para agradecer a Dios los dones recibidos; a continuación sube al paraíso y despierta del sueño.

\section{LOS TRES PETRARCAS}

Poco más tarde, Juan de Lucena convoca de nuevo a Santillana y a los citados, y también difuntos, Cartagena, y Mena, representantes respectivos de los tres estamentos «autorizados» (la nobleza, el alto clero, y el intelectual

40. Cancionero castellano del siglo XV, ed. R. Foulché Delbosc, 2 vols., Madrid, BAE, 1912, II, p. 536. 
profesional: a sus ojos, lo más cercano a un humanista) para su diálogo de vita beata, llamándoles, en la dedicatoria a Enrique IV, antonomásticamente Petrarcas:

al reverendo Alfonso de Cartagena, présul burguense, fago mantenedor de la cuestión, y al magnífico Ínigo López de Mendoza, marqués de Santillana, con el príncipe de nuestros poetas, Juan de Mena, como si vivos altercasen, ventureros; do al partir de la tela, intervengo... Resuscité estos Petrarchas, sepelidos de días, porque de su gravísimo nombre haya este mi libelo mayor autoridad ${ }^{41}$.

La convocatoria de estos Petrarcas, ya «sepelidos», tiene dos significados principales: uno, político, pues fueron tres personas muy cercanas al poder; otro cultural, al presentárnoslos como auctoritates, como pilares de un canon moderno y estrictamente español, capaces de asumir las condiciones de la translatio studii a que aludía Diego de Burgos, y una potencial translatio imperii. El que mejor representa los «nuevos valores», donde confluyen la virtus guerrera y las litterae, es Santillana; a Mena, por su parte, lo caracteriza Cartagena como el "poeta mayor", pues «en nuestra edat, ni conocemos poeta mayor de ti ni semejante: tú jurisconsulto, tú metafísico y grand virgilista» (p. 114). Una síntesis de las aspiraciones intelectuales de aquellos tiempos: el derecho, la filosofía-teología y la poesía clásica, que le han hecho tener «magrescidas las carnes por las grandes vigilias tras el libro, mas no durescidas y callosas de dormir en el campo; el vulto pálido, gastado del estudio, mas no roto ni recosido por encuentros de lança» (p. 131).

Pero el nombre y condición del primer humanista, Petrarca, no sólo era un referente para un poeta, romancista o culto, como Santillana o Mena, sino también para los que cultivaban la teología o la filosofía moral, como Cartagena; o la historia, como López de Ayala o Palencia; la erudición, como Villena o el Tostado, etc., etc. ${ }^{42}$. Porque, a la postre, la obra latina

41. Libro de vita beata (1463), ed. A. Paz y Meliá, en Opúsculos literarios de los siglos XIV a XVI, BAE, Madrid, 1892, pp. 103-205, esp. 106-107; complétese con L. Binotti, «La Epistola exhortatoria a las letras de Juan de Lucena: humanismo y educación en la Castilla del siglo XV», La Corónica, 28, 200, 51-80; G. M. Cappelli, El humanismo romance de Juan de Lucena, Universidad Autónoma de Barcelona, Bellaterra, 2002. M. Morrás ( Sic et non: En torno a Alfonso de Cartagena y los studia humanitatis», Evphrosyne, XXIII (1995), pp. 333-346) lo interpreta como un homenaje de Lucena a los tres grandes maestros de su generación. Obviamente, se trata del llamado 'humanismo vernáculo' o prerrenacimiento; cuyas características describe, por ejemplo, M. R. Lida, Juan de Mena, poeta del Prerrenacimiento español [1950], El Colegio de México, México, 1984².

42. Cf. F. Rico, "Philology and Philosophy in Petrarch», en Intelectuals and Writers in Fourteenth-Century Europe, eds. P. Boitiani y A. Torti, Tubinga-Cambridge, Gunter Narr- 
del toscano es un compendio de todas las disciplinas, como las citadas, y de la filosofía natural, la elocuencia, la filología en suma. Y aunque todas contienen una parte del verum, únicamente a la poesía compete iluminarlo, una vez desvelado su constitutivo figmentum ${ }^{43}$. De modo que, salvedad hecha de la naturaleza imaginativa de su lenguaje, el verum del poeta no es diferente de lo que el historiador, el filósofo moral o el natural consideran verdadero. Recuérdese que si Petrarca suele optar por la voz figmentum, referida a la poesía, no es sólo para atenuar la idea del necesario velamen poético ${ }^{44}$, sino también para subrayar la naturaleza intrínsecamente libre de la creación literaria. No se trata de «cubrir» la sustancia de la verdad, sino, más bien, de exaltarla, pues la forma poética sería como el plato de oro, no el cibum en sí mismo ${ }^{45}$. Para las personas cultas, en esa oscuridad reside precisamente el mérito de la poesía y su dulzura; en este personal y difícil descifre radica gran parte del placer que procura ${ }^{46}$. El vulgo no sabe extraer de allí la veritas rerum ${ }^{47}$.

D. S. Brewer, 1986, pp. 45-66; Idem, El sueño del humanismo. De Petrarca a Erasmo [1993], Barcelona, Destino $2002^{2}$. En general, Bernard Quilliet, La tradition humaniste, Paris, Fayard, 1981, pp. 203-211 y passim; William J. Bouwsma, A Usable Past. Essays in European Cultural History, Berkeley, University of California Press, 1990.

43. El componente estético y formal como un «valor añadido» de la poesía encuentra en la cuarta senile su definitiva defensa, porque la de la poesía es una verdad que, para ser descifrada, exige cultura y gusto, ya que «fere nullus apud hunc poetam versus sine tegmine est» (Seniles, IV, 5). Con todo, en la Collatio laureationis, IX, 7 (1341) ya defendía con vehemencia la verdad de la poesía, diciendo que sería muy fácil demostrar que los poetas «sub velamine figmentorum, nunc physica, nunc moralia, nunc historias comprehendisse».

44. El velo poético es necesario porque el cortante filo de la verdad podría herir el ojo; es la nube que suaviza las aristas del objeto, difumina sus límites y, así, atrae al observador: «... mulceat exterius tantum, alliciatque tuentes» (Epistola a Zoilo, I, p. 228).

45. Así parece desprenderse de la citada Collatio laureationis, IX, 5: «Cum officium poete in eo sit, ut que vera sunt in alia specie obliquis figurationibus cum decore aliquo conversa traducat». También pueden verse Rerum memorandum, III, 50 y 89; Secretum, II; Familiares, XIV, 1, 15; Disperse, XIV; etc., etc.

46. Lo formula en varios sitios muy claramente: «Non illa licentia vatum est / quam multis placuisse palam est./ Scripturum iecisse prius firmissima veri / fundamenta decet, quibus inde innixus amena / et varia sub nube potest abscondere sese...» (Africa, IX, $90 \mathrm{ss}$ ); también en las Familiares, X, 5, 12: «sunt qui clam pergant et velut aperta evitantes umbris gaudeant, neque se profanari et nimia familiaritate contemni, sed videri a paucis et studio queri velint. Hi sunt poete». Cf. supra, Seniles, IV, 5.

47. Véanse las excelentes páginas de Francisco Rico, Vida u obra de Petrarca, I. Lectura del «Secretum», Padua-Chapel Hill, University of North Carolina, 1974, pp. 196-197. En mi artículo «Una nota sobre el escolasticismo poético en el otońo de la Edad Media», Scriptura, XIII (1997), pp. 19-31, recojo la bibliografía pertinente; trazo el largo camino del término y del concepto hasta los albores del Humanismo en «La ficción y la 'verdad del entendimiento': 
En la Castilla del Humanismo incipiente, la versión «laica» más difundida de las afirmaciones de Petrarca es la que recapitula a mediados del XV uno de los Petrarcas de Lucena y el mejor representante del primer grupo: otra vez Santillana, que se sentía heredero de la tradición exegética para romancistas - lo recordaba Diego de Burgos-, que podía haber conocido leyendo algunos de aquellos pasajes de Petrarca o los muchos libros glosados de su biblioteca. En este sentido, diferenciaba a los trovadores, o decidores, de los poetas, como Francisco Imperial, puente con los escritores italianos ${ }^{48}$, cuyas «obras se muestran de más altos ingenios, e adórnanlas e compónenlas de fermosas e peregrinas historias» ${ }^{49}$. El poeta, para Santillana, se asocia con la poesía "sabia», que, además de la técnica trovadoresca, ha asimilado e incorporado toda la tradición medieval, la fusión de lo pagano y lo judeocristiano, renovándola con algunos auctores de la Antigüedad recientemente exhumados, que trae como fuentes o como referentes para su aplicación alegórica o uso ejemplar. Así, cuando al principio de su Prohemio e carta recuerda que la poesía es un "fingimiento de cosas útiles, cubiertas o veladas con muy fermosa cobertura, compuestas, distinguidas e escandidas por cierto cuento, peso e medida» (p. 52), tiene presentes algunos de los principales tópicos, conceptos y tradiciones ${ }^{50}$. Por una parte, la tradición

algunas consideraciones de poética medieval», Revista de Poética Medieval, IV (2000), pp. 153-186; cf. Julia Butiñá, «Algunas consideraciones sobre poética medieval en el humanismo catalán: Bernat Metge y el Curial e Güelfa», Revista de Poética Medieval, XII (2004), pp. 11-52.

48. «El nombre de Francisco Imperial encabeza casi todos los estudios de la fortuna de Dante en España» apuntaba doña Margherita Morreale («El Decir a las siete virtudes de Francisco Imperial. Lectura e imitación renacentista de la Divina Comedia», en Estudios dedicados a Rodolfo Oroz, Santiago de Chile, 1967, pp. 307-367); véanse también Colbert I. Nepaulsingh, ed., Francisco Imperial, "El Dezir a las syete virtudes» y otros poemas, Madrid, Espasa-Calpe, 1977; o Joaquín Forradellas, «Aproximación a la lectura del Decir a las syete virtudes", en Juan Alfonso de Baena y su "Cancionero", eds. J. L. Serrano Reyes y J. Fernández Jiménez, Baena, Diputación Provincial de Córdoba, 2001, pp. 153-160, que subraya este aspecto: «Imperial es, ante todo, un poeta intelectualmente aristocrático y voluntariamente difícil, que anuncia el prerrenacimiento que florece en Santillana y madura en Mena» (p. 155).

49. Prohemio e carta, edición de Ángel Gómez Moreno, Barcelona, PPU, 1990, p. 58; véanse también Francis Ferrie, "Aspiraciones del humanismo español del siglo XV. Revalorización del Prohemio e carta de Santillana», RFE, LVII (1974-75), pp. 195-209; Carmen Marimón, "Las claves retóricas del discurso poético en el Medioevo: la tópica horaciana mayor», Revista de Poética Medieval, VIII (2002), pp. 111-143, 134-135. Cf. Lola Badia, «La legitimació del discurs literari en vulgar segons Ferran Valentí», en Intel.lectuals i escriptors a la baixa Edat Mitjana, eds. L. Badia y A. Soler, Barcelona, Curial-Abadia de Montserrat, 1994, pp. 161-184.

50. En las pp. 91-97 trae Gómez Moreno las principales fuentes de cada uno de los 
que al verbo fingere, de valor claramente figurativo, lo hace sinónimo de 'componer, representar, dar forma o figura, expresar con imágenes el pensamiento o las cosas imaginadas'. Porque Petrarca remacha en sus Invective contra medicum, traducidas por Hernando de Talavera más tarde,

oficio de poeta no es fengir ni menos mentir... oficio de poeta es adornar y componer la verdad de las cosas con fermosas coberturas por que sea oculto al vulgo, de que tú eres parte última y postrimera, pero a los estudiosos e ingeniosos lectores trabajosa en buscar y dulce en fallar. En otra manera, si falsamente crees (como los necios suelen, que lo que non pueden alcançar vituperan) que oficio de poetría sea mentir, quiero luego que creas que eres el mayor de los poetas tú, cuyas mentiras son cerca más que palabras ${ }^{51}$.

Con las "cosas útiles», por otra, Santillana puede estar refiriéndose al tradicional hermanamiento de poesía y teología (o verdad), o sea, a la tesis de que los mitos poéticos expresan velada o alegóricamente 'verdades universales' de una primitiva teología. Aunque también puede ser $-\mathrm{y}$ es lo más probable- que con tan vaga expresión Santillana simplemente señale que las fábulas y mitos poéticos han de tener una finalidad eminentemente didáctica, moral, añadidas o no a la ornamental ${ }^{52}$, tal como Villena, representante del segundo círculo, le enseñó en la traducción de la Eneida,

conceptos que combina Santillana y muchos paralelos; véase también Francis Ferrie, «Aspiraciones del humanismo español del siglo XV. Revalorización del Proemio e carta de Santillana», RFE, LVII (1974-75), pp. 195-209; complétese con las notas de R. Rohland de Langbehn a su edición de Comedieta de Ponza, sonetos, serranillas y otras obras, pp. 14 y 287-288. Julian Weiss dedica íntegramente al Prohemio el capítulo V de su The Poet's Art. Literary Theory in Castile, c. 1400-60, Oxford, The Society for the Study of Medieval Languages and Literature, 1990, pp. 165-228, especialmente pp. 190-200; complétese con Fernando Gómez Redondo, Artes poéticas medievales, Madrid, Laberinto, 2000, pp. 171-186. Cf. el excurso de Lola Badia, Tradició i modernitat als segles XIV i XV, Institut Universitari de Filologia Valenciana-Abadia de Montserrat, Valencia-Barcelona, 1993, pp. 134-138; Idem, "L'humanisme català: formació i crisi d'un concepte historigràfic», en De Bernat Metge a Joan Rois de Corella, Barcelona, Quaderns Crema, 1988, pp. 13-38.

51. Cito por Francisco Rico, ed., Francisco Petrarca, Obras, I, Madrid, Alfaguara, 1978; la traducción, titulada Reprensiones y denuestos contra un médico rudo y parlero, a cargo de Pedro M. Cátedra, pp. 382-410, 384.

52. Así lo cree Ottavio di Camillo, El Humanismo castellano del siglo XV, pp. 79-81, recalcando que «es verdad que Santillana define [la poesía] como fingimiento, pero es de 'cosas útiles', no de verdades inmutables. E incluso si por esta vaga 'utilidad' entendemos ética, su definición todavía deja fuera de la poesía aquellas primeras causas y principios que los antiguos asignaron a la filosofía y los modernos a la teología... En sus poemas... las alusiones a las figuras míticas sirven primariamente como ornamento, y aun cuando son empleadas como ejemplo moral, la lección es transmitida de un modo explícito y sin disfraz». 
desde la concepción de Virgilio como vate ${ }^{53}$. Está enlazando con la tradición del velamen y del integumentum ("cubiertas o veladas con muy fermosa cobertura» ${ }^{54}$ ) y con la representada por el modelo de Imperial, Dante, para quien la poesía es "fictio rethorica musicaque poita» ${ }^{55}$, donde viene a decir

53. «En esta obra Virgilio introduce virtuosas costumbres, inclinando los oyentes a bien facer, siquiera en los votos e sacrificios que facía, inclina no poco a la religión; aprobando las piadosas obras en las afruentas en que se vido Eneas e cómo las pasó sin temor o flaqueza... E por esta manera toda su ystoria es llena de fructuosa doctrina e, si el leedor supiera prescrutar el poethal intento, en tal manera que cualquier de los estados del mundo e cada una de las edades e cual pluguiere de las regiones e religiones puede tomar doctrina e libre vevir virtuosamente. Cuéntase por Servio en la glosa que fizo sobre el Virgilio de los grandes misterios en esta Eneyda contenidos, afirmando que en el primero libro, por integumentos methafóricos e fabulosos, representa todo lo que en la primera contesce edat al nuevo hombre veniente en el mundo, en aquel Eneas representado. E ansí, en el segundo, de la segunda edat... Ansí que es un espejo doctivo en do cada uno puede contemplar su vida, las faltas e reparaciones de aquélla». Son palabras del proemio; apud Pedro M. Cátedra, ed., Enrique de Villena, Traducción y glosas a la "Eneida», I, pp. 25-26.

54. Villena lo explica excelentemente: «De manera que piensa el simple leedor que Virgilio quiere contar en esta obra los fechos de Eneas, e aquel ministra loores de Octhoviano: so el velo poéthico [glosa: Velo llama a la cubierta o palliación con que los poethas suelen fablar, que ansí como el velo cubre la cosa sobre que está, pero non tanto que por su delgadez non se conosca que algo está deyuso e se muestra, aunque non tan claramente como sin velo, ansí los decires poéthicos fablan por tales encubiertas, que a los non entendidos paresce escuro e velado e a los entendidos claro e manifiesto, segund fizo Virgilio cuando fabló de Eneas, que paresce que lo diga por contar los fechos de Eneas, e su intinción es decir por aquellas palabras lo de Octhoviano, como en este texto se rescita...] e colores retoricales discretamente e pallidiada fiere aquel señal a do non parescía tirar» (ed. cit, I, p. 24, glosas, entre paréntesis cuadrados, en las pp. 49-50, cursiva mía). Remito al excelente artículo de Pedro M., Cátedra, «El sentido involucrado y la poesía del siglo XV. Lecturas virgilianas de Santillana con Villena», en "Nunca fue pena mayor». Estudio de literatura española en homenaje a Brian Dutton, eds. A. Menéndez Collera y V. Roncero, Cuenca, Universidad de Castilla-La Mancha, 1996, pp. 149-161, donde a propósito del último fragmento muy acertadamente indica que "esta imagen del entrenamiento venatorio o de tiro al blanco está expresando ya implícitamente, por un lado, la libertad del autor, y, por el otro, la del lector, lo cual no deja de ser admirable a estas alturas» (p. 151); también tiene razón cuando dice que la utilización de la privativa técnica de la exégesis del sentido involucrado al terreno de la literatura laica la banaliza y deja la puerta abierta a interpretaciones extemporáneas, que nada tienen que ver con la búsqueda de la verdad encubierta de los maestros medievales como Bernardo Silvestre o Guillermo de Conches; cf. J. Weiss, The Poet's Art, pp. 191-192.

55. De vulgari eloquentia, II, iv, 2. Dante inscribe la frase para ilustrar especialmente que versificari y poetari, versificator y poeta significan lo mismo, por lo que remacha «[qui vulgariter versificantur] prorsus poete sunt, si poesim recte consideremus; que nichil aliud est quam fictio rethorica musicaque poita». Véase A. Schiaffini, "Poesis e poeta in Dante», en Studia philologica et litteraria in honorem Leo Spitzer, eds. A. G. Hatcher y K. L. Selig, Francke, Berna, 1958, pp. 379-389. 
que la poesía es una fictio (con el valor de 'composición') que se llama poesis porque está poita ('hecha, compuesta') con el concurso de la retórica y la música, o sea, de la métrica.

\section{El DECIR ALEGÓRICO. JUAN DE MENA Y LA CULMINACIÓN DEL ARTE MAYOR}

De estos planteamientos deriva Santillana el decir alegórico, muchas veces sub specie de visión, sueño, viaje imaginario, o una combinación de los tres ${ }^{56}$. Pues aunque fue cultivado previamente por los poetas del Cancionero de Baena, especialmente por el citado Imperial o por Diego de Valencia, la cuidada dispositio de los poemas mayores de Santillana le darán la dignidad que requerían la alta inventio y esmerada elocutio que habrán de seguir desde Juan de Mena hasta sus émulos finiseculares como Juan del Encina o Juan de Padilla, el Cartujano. Porque Santillana supo dotarlos de erudición clasicista, vocabulario y sintaxis latinizante, temas elevados, políticos y morales, y, por supuesto, el arte mayor, que llevará a la perfección Juan de Mena (véase abajo) en el Laberinto de Fortuna (1444), mejorando los planteamientos poéticos de los últimos años del Marqués. Incluso cuando Jorge Manrique y sus seguidores se decidieron a cultivar los géneros menores, a base de reelaborar los componentes más herméticos «de una tradición poética basada en la annonimatio, la repetitio y el conceptismo, se movieron en el núcleo de los elementos característicos de una cantera poética que Santillana había recuperado desde una tradición más arcaica, aunque un tanto abandonada..., por los poetas del siglo XIV» ${ }^{57}$. No previó, con todo, la pujanza que tuvo la poesía de tipo tradicional desde fines del siglo XV ni el rápido envejecimiento del arte mayor. Pero, en otro orden de cosas, sí fue capaz de la modernidad radical del "Bías contra Fortuna», donde, retomando unos versos de los Proverbios (1437), se contempla, desde la perspectiva estoica, el suicidio como «un sublime acto de magnanimidad» ${ }^{58}$. Sin que ello suponga renunciar

56. Jacques Joset, «Sueños y visiones medievales: razones de sinrazones», Atalaya, VI (1995), pp. 51-70.

57. Vicente Beltrán, estudio preliminar a la edición de Regula, Rohland de Langbehn de la Comedieta de Ponza, sonetos, serranillas y otras obras, p. XXIX; complétese con Vincent Serverat, "Le Laberinto de Fortuna de Juan de Mena ou le crépuscule du dit médiéval», en La poésie castillane de la fin du Moyen Âge au début du Siècle d'Or, coord. J. Battesti Pelegrin, Paris, Editions du Temps, 1997, pp. 11-35.

58. Paolo Cherchi, «Pero Díaz de Toledo y su Diálogo e razonamiento en la muerte del marqués de Santillana», en Historias y ficciones, eds. R. Beltrán, J. L. Canet y J. L. Sirera, Valencia, Universidad, 1992, pp. 111-120, 115. 
a la preeminencia de la littera bíblica sobre la poética ${ }^{59}$. Santillana, en fin, defiende la libertad creativa, vinculada a la voluntas auctoris, como vimos hacía Petrarca a la vista de San Agustín. Es una paradoja que los autores menos litterati, como él, sean más libres y estén más cerca del litteratissimus Petrarca que los más letrados, como Cartagena o el Tostado, y más cerca de su hermenéutica, a pesar de no conocerlo profundamente.

Sea cual sea el contenido o trascendencia de la «verdad» encubierta de la poesía que postula Petrarca, o el de la «utilidad» velada de Santillana, aquella verdad y esta utilidad, de la que ya se han desprendido las siempre obligadas interpretaciones alegóricas de antańo, particulares e inmanentes -a veces «subintellectas» al decir de Villena ${ }^{60}$-, se perciben, se difunden y se retienen mejor con el concurso de imágenes, fábulas, figuras o mitos ${ }^{61}$. No

59. «E así, concluyo, ca esta ciencia, por tal, es acepta principalmente a Dios, e después a todo linage e especie de gentes. Afírmalo Casiodoro en el libro De varias causas, diciendo: 'todo resplendor de eloqüencia e todo modo o manera de poesía o poetal locución e fabla, toda variedad de honesto fablar hobo e hobieron començamiento de las Divinas Escripturas'»(edición citada, p. 55).

60. «En tal guisa [traduje a Virgilio], que alguna cosa non es dexada o pospuesta, siquiere obmetida, de lo contenido en su original, antes aquí es mejor declarada e será mejor entendida por algunas expresiones que pongo acullá subintellectas, siquiere implícitas o escuro puestas... Esto fice porque ser más tractable e mejor entendido e con menor estudio e trabajo vós, señor, e aquellos podades sentir, siquiere mentalmente gustar el fructo de la doctrina latente [glosa: significa escondimiento, e maguer adelante se declaró que decir quede cosa cubierta por mengua de los romanciales vocablos, pero mayor significación de encubrimiento tiene el vocablo "latente» que "encubierto", porque "latente» muestra muy grand encubrimiento con dificultad de parescer, e el "encubierto" muestra escondimiento sin dificultad de se poder fallar], siquiere cubierta, en el artificioso decir» (I, p. 32); en cursiva la glosa correspondiente (Ibidem, p. 65).

61. Francine Mora-Lebrun ( $L^{\prime}$ "Enéide» médiévale et la naissance du roman, PUF, París, 1994, pp. 89-108) da buena cuenta de la importancia de las glosas virgilianas para la creación de nuevas ficciones y figurae. En nuestras letras baste ver la imaginación que les pone Villena a las «investigaciones» de Virgilio: «Pues pensando Virgilio en su alta investigación por qué manera e más coloradamente sin mostrar adulación podría representar e publicar los imperiales loores del virtuoso príncipe Octhoviano, considerando de todas las loables cosas era doctado, sólo de una fallescido, que las otras difuscava o menos claras rendía, es a saber, era de pequeño, siquiere baxo, linage... ocurrióle para reparar la mengua... era convenible introducir la ystoria de Eneas e traer por succesiones de tiempos de cuál Octhoviano descendía linage con fermosas simulaciones [glosa: quiere decir veno a su imaginación que de lexos acarrease el de Octhoviano linage, e començólo de tan grand persona como Eneas, para mostrar que era grande e antiguo, contra lo que dél se dicía... e aqui se muestra la prática que han de tener los ystoriadores cuando han de reparar alguna falta: que traigan luengos acarreos, e paresce más verdad e puede ser menos contradicho]. E por las respuestas que finge que fueron a Eneas dadas en la descendida del ynfierno, introduce las virtudes, fama, gloria e dilactada señoría de aquél seer vaticinadas e cuántos provecho vendrían al mundo de su dominación, por muchas afirmando testificaciones siglos dorados en su tiempo seríen como en los días de Saturno» 
es preciso recordar que el procedimiento era tan habitual como el propio acto de escribir. Baste traer un testimonio de tiempos no muy posteriores a los de Santillana: el del humanista salmantino Giacomo Publicio ${ }^{62}$, que volverá a demostrar su aplicación práctica en su Oratoriae artis epitoma (Venecia, 1482), donde indica que las intentiones simplices y "espirituales» deben ser ayudadas por alguna «similitud corporal»; si no, desaparecen muy rápidamente de la memoria, pues las imágenes tienen, precisamente por su collocatio in locis, la capacidad de fijar en el recuerdo las ideas, los términos y las nociones ${ }^{63}$.

El tercer Petrarca, Juan de Mena lleva al extremo, como digo, el llamado arte mayor, perfeccionado por Santillana, aun siendo muy consciente de que

\footnotetext{
Non me conmueve la gran disciplina de la poesía moderna abusiva, nin hobe bebido la linfa divina, fuente de Phebo, muy admirativa, nin sope el camino por qué lugar iba la selva Safos en el monte Parnaso, mas causa me mueve del daño que paso, que fuerças y seso y bienes me priva ${ }^{64}$.
}

(«Claro Escuro», XV, 134-141)

Sabía que ceñirse a "la gran disciplina / de la poesía moderna abusiva» suponía alejarse del uso normal de la lengua y asumir la artificiosa convención poética del arte mayor, para intentar dotar al lenguaje y contenido de sus obras de una dignidad estética que no desmereciera frente a las prestigiosas poética y poesía latinas e italianas, principalmente con el anisosilabismo y ostensible presencia de determinadas marcas fónicas del verso de arte mayor, pues su ritmo dactílico se parecía al del hexámetro latino, como recordaba Gonzalo García de Santa María: «según la natura del verso latino, que va a pares e es hexámetro, no me parecía le respondiese otra specie de coplas».

(ed. cit., I, p. 24 el texto en la p. 49).

62. Cf. Agostino Sottili, Giacomo Publicio «Hispanus» e la diffusione dell'Umanesimo in Germania, prólogo de Francisco Rico, Universidad Autónoma de Barcelona, Bellaterra, 1985.

63. Op. cit., f. 4r. Cf. Paolo Rossi, Clavis universalis, Grenoble, Millon, 1993, pp. 47-48.

64. Cito por la edición de Miguel Ángel Pérez Priego, Obras completas, Barcelona, Planeta, 1989; Carla De Nigris lee «conviene» en vez de "conmueve» (v. 134). El sentido no difiere demasiado, pues el poeta explica que no ha bebido en la fuente de Apolo, sino que a la poesía le han conducido «el daño que paso» (v. 140), que le priva de «fuerças y seso y bienes»; es «el tópico de la insuficiencia del poeta» (ed. cit., p. 28, nota). 
Pero, además de la métrica, de aquellos modelos también quisieron emular el contenido, los artificios expresivos y el concepto mismo de poesía, pues la quisieron, como la de los latinos, capaz de acomodar contenidos prestigiosos, resonancias culturales clasicistas y elevada retórica. Mena acabó rechazando las manifestaciones puramente externas del Humanismo trasplantado, pues, por lo general, en sus primeras manifestaciones consistió en unas cuantas pinceladas mitológicas, en ciertos usos exóticos de latinismos o en una imaginería erudita (concebida la Antigüedad como galería de ejemplos) con que estar a la altura de la modernidad, pero apenas se ahondó en otros aspectos.

Pese a haber compuesto medio centenar de poemas encuadrados en los principales temas y géneros de la lírica cortesana (canciones y decires amorosos, piezas políticas y de circunstancias, preguntas y respuestas, enigmas y coplas satíricas) que gozaron de una amplia aceptación, pues no en balde figuran en más de treinta cancioneros y fueron recogidos en las tantas veces editadas Obras del famosissimo poeta Juan de Mena, comentadas por Hernán Núnez (1499) o el Brocense (1582), como si fuera un autor clásico; pese a que en sus "coplas de amores en la verdad es singularíssimo" -al decir de Juan de Valdés-, Mena siempre consideró (con el asentimiento de la crítica posterior) que sus obras de mayor aliento poético eran las escritas al amparo de la poética del arte mayor ${ }^{65}$. No sólo porque la 'elevada' materia requería la métrica, el ritmo y la lengua que dicha poética favorecía, sino también, y especialmente, por su mayor versatilidad y libertad formal, aun dentro de ciertas rigideces métricas y rítmicas, que permitía demostrar un saber plagado de auctoritates y exempla. Como consecuencia, el arte mayor violentó la prosodia, la norma gramatical y el léxico. Porque la férrea «disciplina abusiva» rítmica, métrica, retórica y cultural se distanció de la lengua usual para dar cabida en versos de tan larga andadura a latinismos osados y extravagantes, arcaísmos, enumeraciones de exempla de la Antigüedad, remedos de estructuras sintácticas latinas, alegorías de raíz dantesca y toda suerte de recursos que permitieran hacerse con una poética culta propia, que emulara la de los grandes modelos italianos y que conviniera al estilo elevado, sublimis, y al contenido grave.

Testigo, Juan del Encina, que en su Arte de poesía castellana (1496) indicaba que «el arte mayor es más propia para cosas graves y arduas», establecía la diferencia métricamente y le buscaba un ancestro ilustre:

65. Sin dejar de lado el arte menor, como apunta una y otra vez doña Ma Rosa Lida, Juan de Mena, poeta del Prerrenacimiento español [1950], México, El Colegio de México, 1984². Cf. Ma Amor Martín Fernández, Juan de Mena y el Renacimiento. Estudio de la mitología en su obra menor, Córdoba, Caja de Ahorros, 1985. 


\section{LA AUTORIDAD LITERARIA}

Hay en nuestro vulgar castellano dos géneros de versos o coplas: el uno, cuando el pie consta de ocho sílabas o su equivalencia, que se llama arte real; y el otro, cuando se compone de doce o su equivalencia, que se llama arte mayor. Digo su equivalencia, porque bien puede ser que tenga más o menos en cantidad, mas en valor es imposible para ser el pie perfeto; y bien parece nosotros haber tomado del latín el trovar, pues en él se hallan estos dos géneros ${ }^{66}$.

No obstante las palabras de Encina, a primera vista lo más sorprendente del arte mayor es su versificación, es decir, las normas métrica y rítmica, porque es un verso anisosilábico (oscila entre las diez y las catorce sílabas, aunque tiende a regularizarse en doce), dividido en dos hemistiquios que invariablemente presentan cada uno dos tiempos marcados y separados entre sí por dos sílabas átonas, independientemente de donde recaiga el primer ictus, como se comprueba en estos versos del Laberinto:

quándo quedávan e ír lo veían (181f)

ó o o ó o o ó o oóo

Aristótiles cérca del pádre Platón (118c)

o o ó oo ó o o ó o o ó

Pero precisamente por ser una «disciplina abusiva», puede recaer el ictus en una sílaba usualmente átona:

nin fuérza de yérvas, nin vírtud de piédra $(110 g)$

o ó o o ó $\mathrm{o}$ o ó

e incluso puede haber dos ictus en una misma palabra o segmento fónico:

¡O flór de sabér e de cávallería (124a)

o ó o o ó o o ó o oóo

dé los sus ínclitos prógenitóres. (143d)

ó o o ó o o ó o óo

La repetición sistemática de este riguroso esquema acentual (ó o o ó), que no silábico, surte un vigoroso efecto rítmico, muy conveniente con el género y contenido sublime que quiere alcanzar el poeta. Con todo, lo más importante de la adopción de este modelo de verso, de esta "coacción del

66. Cito por la edición de Francisco López Estrada, incluida en Las poéticas castellanas de la Edad Media, Madrid, Taurus, 1984, pp. 66-93, 86. Cf. Julian Weiss, «Tiempo y material en la poética de Juan del Encina», en Humanismo y literatura en tiempos de Juan del Encina, ed. J. Guijarro, Salamanca, Universidad, 1999, pp. 241-257. 
ictus», como la llamó Lázaro Carreter en su lúcido estudio ${ }^{67}$, no afecta sólo al verso y al ritmo, sino que se convierte en un sólido patrón que modelará artificiosamente la lengua, creando una profunda distancia entre la lengua del verso y el idioma común. Una vez lograda la distancia (y ahí está la paradoja cuando invocan como dechado el latín), los poetas prescinden no sólo del modelo latino, sino también del uso coherente del castellano, estén forzados por el ictus y demás requisitos del arte mayor o no lo estén, pues hay otros fenómenos sintácticos y retóricos: violentos hipérbatos («Divina me puedes llamar Providencia», 23h), oraciones de infinitivo o participio presente a la latina («Desque sentida la su proporción / de humana forma non ser discrepante», 22a-b) y un largo etcétera que detalló María Rosa Lida.

\section{LA DECADENCIA DE UNA ESTÉTICA ERUDITA}

Al final de su vida, Mena, al fin y al cabo curial entre aristócratas, se dio cuenta de que los artificios del arte mayor y la recreación clasicista que comportaban no convenían al contenido moral de la poesía, en concreto de las Coplas de los siete pecados mortales. Es posible que fuera consciente de que, a diferencia de las italianas, las letras españolas de su tiempo no conseguían la adecuación de ambos planos, moral y estético, por lo que resultaba perjudicial el uso atolondrado de la cultura clasicista:

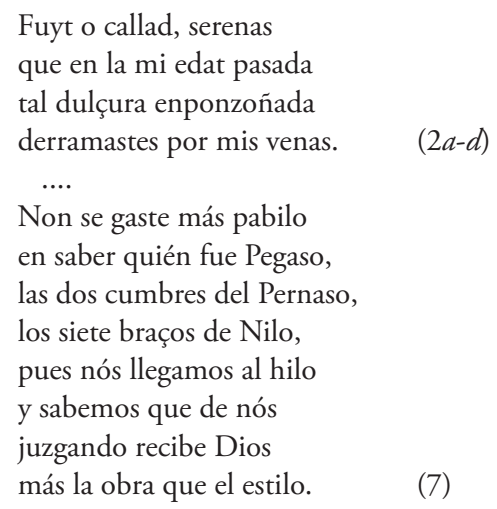

Sabiéndose primus inter pares, las Coplas serían como un antídoto de la «dulçura emponzoñada»(2c) que rezumaban aquellas obras clásicas mal

67. «La poética del Arte mayor castellano» [1972], ahora en Estudios de poética (la obra en sí), Madrid, Taurus, 1976, pp. 75-111. 
asimiladas o leídas sin criterio. Es posible que se diera cuenta de que utilizar la «materia» antigua únicamente para dotar de "estilo» elevado a ciertas composiciones no tenía ningún sentido, ${ }^{68}$ por lo que, tras invocar a la "cristiana musa», despide a los gentiles. Consecuente con el contenido, el decoroso estilo de estas coplas de arte real (que siguen bullendo en ecos clásicos, aunque a contrario) está muy lejos de los violentos latinismos y estructuras sintácticas del arte mayor. Llega incluso a denostar las alusiones cultas dudosamente morales: «A Dido con otras gentes / infamo munchas vegadas» (9a-b), y, en fin, a desterrar la dulcedo gentil: "Cese nuestra fabla falsa / de dulce razón cubierta» (11a-b). En su palinodia reivindica la ejemplaridad y gravedad de una poesía libre de la esclavitud rítmica del arte mayor y de la imaginería erudita a base de ejemplos y fábulas sacados de los repertorio la Antigüedad:

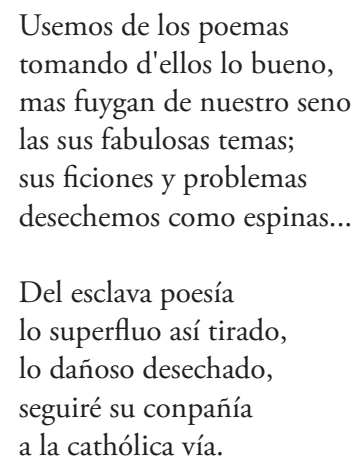

$(14 a-f, 16 a-e)$

En estas últimas obras de Mena, así, se aprecia una actitud que recuerda al Cartagena del Oracional o al Pérez de Guzmán de los Loores de los claros varones de España (ca. 1450):

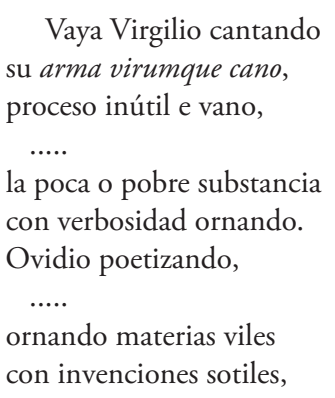

68. César Domínguez, El concepto de «materia» en la teoría literaria del Medioevo, Madrid, CSIC, 2004, pp. 124-129. 
su alto estilo elevando.

Aquestas obras baldías

parecen al que, soñando,

falló oro e, despertando,

siente sus manos vacías;

asaz emplea sus días

en oficio infructuoso

quien solo en fablar fermoso

muestra sus filosofías.

Ahora Mena quiere manifestar la necesidad de alejarse de algunas lecturas iniciales y de su aplicación literaria, pues parece llegar a la conclusión de que no aportaban nada a la gravedad y profundidad moral requeridas por el quehacer literario o intelectual. Así, en las Coplas cantará una palinodia con la que pretende poner en evidencia los peligros e impertinencia de cierta erudición superficial, mal asimilada o sin los necesarios fundamentos o resonancias morales, que, por ejemplo, practicó en la Coronación o Calamicleos (1438), en arte real, pero sazonada con latinismos (colaudar, noverca, basis, etc.), hipérbatos y giros latinizantes ${ }^{69}$. En el "Claro escuro" alternó los oscuros recursos y alusiones cultas del arte mayor con la poesía de cancionero, funcionando las canciones en arte real (no menos oscuras, en otro sentido) como una suerte de contrapunto explanatorio de las coplas de arte mayor $^{70}$. Como si desplegara a los ojos del lector ambos recursos y técnicas, alterna coplas «escuras», donde acumulará las referencias clásicas eruditas, y claras, sazonadas con los tópicos amorosos de la poesía de cancionero: una especie de stilus mixtus en que combina dos poéticas distintas y que también utilizará en El fijo muy claro de Yperión.

La incorporación con mayor o menor propiedad de esta cultura del arte mayor en las obras citadas no impidió, al contrario, que la rechazase en las Coplas de los siete pecados mortales. El hecho mismo de que estas inconclusas coplas las continuasen Gómez Manrique, Pero Guillén de Segovia y fray

69. Se apresura a advertir que «irán algunas auctoridades latinas en el siguiente comento, assí métricas como prosaicas. Y de aquesto los no latinos ruégoles no se enojen, ca faze que, vulgarizando el latín, no paresce ['aparece, se muestra'] el arte del latino metro y destrúyese la poesía. Pero fallarán luego lo que quiere cada una dellas dezir, siguiente ['siguiendo'] auctoridad. Y esto se fará en aquellas que es menester declararse, o fueren coadiutorias del propósito principal. Fallarán las partes latinas que fueren escuras truncadas y señaladas en la glosa, y en la letura podrán saber las derivaciones dellas» (cito por la selección de Feliciano Delgado León, "La coronación» de Juan de Mena, Córdoba, Caja de Ahorros, 1978, p. 55).

70. Véanse simplemente Miguel Ángel Pérez Priego, "El 'Claro Escuro' de Juan de Mena”, en El comentario de textos, 4. La poesía medieval, Madrid, Castalia, 1983, pp. 427-449; Francisco Rico, «Aristóteles Hispanus...», pp. 83-90. 
Jerónimo de Olivares, durante los dos reinados siguientes (Enrique IV y los Reyes Católicos), es muy pertinente con la evolución general de la poesía prerrenacentista ${ }^{71}$, mucho más marcada ideológicamente en la segunda generación, por lo que recomienda Pero Guillén:

\author{
No ocupemos el sentido \\ dó son los montes de Gete \\ nin si las aguas de Lete \\ bebidas ponen olvido, \\ ni apuremos si fue Dido \\ más constante que Jocasta, \\ pues tiempo que allí se gasta \\ en fin se halla perdido. \\ y si salvar nos queremos \\ en la fe de cristiandad, \\ fuyamos de voluntad, \\ con razón nos conformemos ${ }^{72}$.
}

\title{
El CÍRCULO INTELECTUAL DEL OBISPO CARRILLO
}

Al parecer, Gómez Manrique y Pero Guillén no harían sino continuar, en el círculo del obispo Carrillo, "la labor de Santillana y de Mena, pero con una clara diferencia evolutiva, en el sentido de conseguir un mayor sincretismo sacroprofano a través de la integración de lo paulinista y lo estoico" ${ }^{73}$. La profunda admiración de Guillén por Mena la subraya él mismo al declararse discípulo suyo, y su obra más larga, el Debate de la Razón contra la voluntad, escrita entre 1469 y 1474, depende directamente del Laberinto, tiene semejantes objetivos y análoga disposición estructural (los siete cercos astrológicos) y reproduce el esquema de la visión a lo Francisco Imperial que

71. Según Carlos Moreno Hernández («Pero Guillén de Segovia y el círculo de Alfonso de Carrillo», Revista de Literatura, XLVII (1985), pp. 17-49), las Coplas de Mena son «una palinodia religiosa..., que hace referencia a la tesis básica de las tres versiones, esto es, la preponderancia de la Razón sobre la Voluntad o apetito, doctrina más de acuerdo con las ideas escolásticas y estoicas que con las del nominalismo franciscano» (p. 32).

72. Pero Guillén, «Continuación del poema de Juan de Mena que comienza 'Canta tú, cristiana musa'», en Obra poética, ed. Carlos Moreno Hernández, Madrid, FUE, 1989, p. 256, vv. 480- 487 y $492-495$.

73. Carlos Moreno Hernández, ed., Pero Guillén, Obra poética, p. 75; complétese con Kenneth Scholberg, Introducción a la poesía de Gómez Manrique, Madison, Wisconsin University Press, 1984, pp. 23-30 y passim. 
emuló Santillana y perfeccionó Mena ${ }^{74}$. Y a Gómez Manrique lo designa como sucesor de Santillana, su tío ${ }^{75}$, el que fuera su secretario y traductor, Pero Díaz de Toledo (ca. 1418-1466), en el prólogo a las glosas a la Querella de la gobernación, del propio Gómez Manrique:

Principia e comienza asimesmo este cavallero Gómez Manrique, el cual, si el tiempo le da logar a continuar e continúa, irá en el alcance a los cavalleros nombrados e publicará su ingenio de buenas e fructuosas $\operatorname{cosas}^{76}$.

Los «nombrados» son Santillana y Pérez de Guzmán, de los que es digno sucesor, tanto por la «forma» como por las sententiae:
este noble cavallero con agudo e sotil ingenio ha principiado a se ejercitar e trabajar en componer graciosos e doctos poemas e metros, así en la forma de componer como en las sentencias de las cosas compuestas. (Ibidem, p. 578)

Por ello merece ser glosada, apunta Díaz de Toledo: "paresció digno trabajo de me ocupar en escrebir alguna glosa e declaración a las coplas por él compuestas». Las glosas son como una pequeña historia literaria de los que escribieron en metro; es como un resumen del Prohemio de Santillana, de quien habla en pasado, al igual que de Pérez de Guzmán; de lo que se induce que lo escribiría después de 1460 (año probable de la muerte de Pérez de Guzmán). Gómez Manrique vendría a ser, así, el continuador de la poesía «seria» y un buen representante del caballero letrado. Junto con Pero Guillén de Segovia, serían las piezas claves del círculo del obispo Alfonso Carrillo, un círculo que, a su vez, fue una suerte de reedición del de Santillana después de su muerte y al comienzo de las desavenencias de parte de la nobleza con Enrique IV. Gómez Manrique y Guillén, como antes Santillana y Mena, son el modelo del caballero y el letrado que comparten intereses ideológicos y culturales, como ocurría en el primero de los grupos citados al principio.

La corte de Carrillo pudo servir de escuela al sobrino de Gómez Manrique, Jorge ${ }^{77}$, además de a Lope de Estúñiga y otros miembros de la

74. Véase la introducción de Moreno Hernández a la edición citada, pp. 77-89.

75. Antes, el sobrino Gómez Manrique le escribió un «Planto de las virtudes», con un excelente prólogo en prosa, dedicado al hijo de Santillana, el cardenal Pedro González de Mendoza (está en la edición del Cancionero de Francisco Vidal González, pp. 362-366).

76. Edición citada, pp. 577-618, 581-582.

77. Antonio Serrano de Haro, Personalidad y destino de Jorge Manrique [1966], Madrid, Gredos, $1975^{2}$, p. 289. 
misma familia ${ }^{78}$; junto con los bufones y conversos de presencia eventual: Juan de Valladolid, o Juan Poeta, y Antón de Montoro. También pasarían por allí letrados conversos como Álvarez Gato o Rodrigo Cota; o clérigos quasihumanistas como Juan de Mazuela y Alfonso de Ortiz, además del citado Pedro Díaz de Toledo. No estarían muy lejos Francisco de Noya y Alfonso de Toledo o Pero Jiménez Rejano; también se incorporaría Alfonso de Palencia, sucesor de Mena en la corte ${ }^{79}$. En este círculo se acaba confirmando aquella progresiva uniformidad entre los distintos estamentos sociales e intelectuales; difuminando las grandes diferencias entre caballeros, letrados y clérigos que advertíamos al principio. Todos, nobles y curiales (no letrados profesionales), se inclinaron por la lectura de libros de carácter ético (Aristóteles, Cicerón, Séneca, Boecio, San Gregorio) y de historia latina ${ }^{80}$, como señalaba Gómez Manrique, que reprende a los caballeros «haraganes» que dicen

ser cosa sobrada el leer y saber a los cavalleros... Yo soy de muy contraria opinión, porque a éstos digo yo ser complidero el leer e saber las leyes e fueros e regimientos e gobernaciones de los pasados que bien rigieron e gobernaron sus tierras e gentes, e las fazañas e vidas e muertes de muchos famosos varones que vida virtuosa vivieron... Las quales dotrinas, ¿̇en quién mejor nin tan bien pueden ni deben ser empleadas que en aquellos que han de gobernar grandes pueblos y gentes diversas en condiciones e calidades?.... A éstos es conviniente darse al templado estudio..., según lo ficieron muchos famosos varones romanos, tebanos, cartagineses y lacedemones ${ }^{81}$.

Para todos es un buen ejemplo su tío Santillana, que, como César, supo «juntar la toga con la loriga» ${ }^{82}$.

Por lo mismo, tanto Gómez Manrique como Guillén de Segovia remedan la invocación sacra de Juan de Mena. Gómez Manrique, en la Consolatoria para doña Juana de Mendoza:

78. John Cummins, "Pero Guillén de Segovia y el Ms. 4114», Hispanic Review, XLI (1973), pp. 6-32, 29.

79. Serrano de Haro, op. cit., p. 290. Véase también Gemma Avenoza, «Lope García de Salazar: La formación de un bibliófilo y de su biblioteca, una visión general», eHumanista, VI (2006), pp. 34-67.

80. Cf. Jeremy N. H. Lawrance, «Nuevos lectores y nuevos géneros: apuntes y observaciones sobre la epistolografía en el primer renacimiento español», en Literatura en la época del Emperador. Academia Literaria Renacentista V, ed. V. García de la Concha, Salamanca, Universidad, 1988, pp. 81-99, 81-82.

81. cito por la edición de Francisco Vidal González, ed., Gómez Manrique, Cancionero, Madrid, Cátedra, 2003, Prólogo a su Cancionero, pp. 98-100.

82. Véase Ottavio Di Camillo, «Humanism in Spain» [1988], pp. 77-80. 
Mas ¿a quién invocaré para sobir esta cuesta?

¿Llamaré en Helicón

a las prudentes hermanas,

o a las thesalianas,

o hurtaré las mançanas

veladas por el dragón?

Que mal podrán socorrerme estos que nada sopieron, enseñarme nin valerme, sin dubda, nin bastecerme del saber que no tuvieron. Pues iré al Hacedor de los cielos estrellados, que supo hacer letrados de hombres desenseñados, sin escuela ni dotor ${ }^{83}$.

"Como en toda la literatura moral del siglo XV castellano, hay aquí un movimiento pendular entre la posición cristiana y el estoicismo» ${ }^{84}$. Por eso mismo, no invoca a las musas, ni traerá ejemplos como el de las manzanas de oro, a pesar de que, como Mena, sí lo hizo en su juventud:

que las gruesas herramientas

con que yo forjar solía

estas obras que hacía,

non de alta policía,

todas están orinientas.

(XIII, 228-232)

El tiempo las ha gastado, que gasta todas las cosas;

(XIV, 234-235)

he andado temeroso,

con muchas dubdas dubdoso,

de començar la carrera,

por estar muy destraýdo

d'esta ciencia poetal

y ser la materia tal. $\quad(X V, 245-250)$

83. Consolatoria para doña Juana de Mendoza (mujer del poeta), ed. cit., VII, 163-164, 168-172; X, 193-202; pp. 456-459.

84. Rafael Lapesa, «Poesía docta y afectividad en Gómez Manrique», en De Ayala a Ayala, Madrid, Istmo, 1988, pp. 55-64, 59. En la segunda consolatoria se hace mucho más notoria «la emotividad franciscana, que en la misma corte de los Reyes Católicos encarnaban Frey Ínigo de Mendoza y Fray Ambrosio Montesino» (p. 84). 
Pero Guillén, por su parte, prefiere citar a Séneca, antes que a Aristóteles ${ }^{85}$, y a Vegecio y Cicerón, a algunos Santos Padres y la Biblia, apostillando que

Non invoco en este paso

ciencias largas nin difusas

nin subsidio de las Musas

que habitan en Parnaso,

nin entiendo proceder

en melodía de canto,

mas invoco a mi querer

tres personas en un ser:

Padre, Hijo, Espírito Santo.

(XXVIII, 19-27)

No muy distante es la actitud (e incluso las palabras) de Jorge Manrique:

Dexo las invocaciones

de los famosos poetas

y oradores;

no curo de sus ficiones,

que traen yerbas secretas

sus sabores.

A Aquel solo me encomiendo,

a Aquel solo invoco yo

de verdad,

que en este mundo viviendo,

el mundo no conosció

su deidad ${ }^{86}$.

(Coplas a la muerte de su padre, IV, 37-48).

El correlato en prosa bien podría ser un diálogo de Alfonso Ortiz contra Lucena (antes de 1475), donde aparece el arzobispo Carrillo como interlocutor junto al estoico Zenón, Platón, Cicerón, Boecio y San Jerónimo, argumentando que la busca de un concepto más humano de moralidad cristiana no impide que placer y virtud sean compatibles ${ }^{87}$.

85. «Fuyendo del filósofo en el su libro de las Éticas por ser largo y difuso et aun en parte obscuro, quise seguir la orden que Séneca tovo en el compendio de las cuatro virtudes, do pone dotrinas y enxiemplos asaz compendiosos y aprovechables» (Prólogo a la Suplicación... cerca de la paz, dirigido al arzobispo Carrillo, en Obra poética, ed. Carlos Moreno, Madrid, FUE, 1989, p. 329). Es posible que el compendio al que alude Guillén sea la colección Proverbios de Séneca llamados Vicios e Virtudes; véase simplemente Karl A. Blüher, Séneca en España, Madrid, Gredos, 1983, pp. 165-168; cf. pp. 223-230.

86. Cito por la edición de Vicente Beltrán, Poesía, Barcelona, Crítica, 1993, pp. $150-151$.

87. Ottavio di Camillo, El Humanismo castellano del siglo XV, pp. 261-263, que lo fecha 
Esta nueva moralidad prefigura y condice muy bien con la estética del mejor poeta de la siguiente generación, Jorge Manrique (1440-1479), pues durante los años de su plenitud poética apenas se cultiva el arte mayor y parece como si en sus poemas no utilizase referencias clasicistas directas, «sino recuerdos de lecturas, asimiladas y transformadas ya» ${ }^{88}$. Poco a poco, se impone el conceptismo; «la adopción de una lengua mucho más cercana a la hablada» ${ }^{89}$; "con un transparencia sentimental rara en la poesía española del período» ${ }^{90}$. Son, precisa y convenientemente, los primeros rasgos de lo que más tarde se llamará petrarquismo, pues la base estética cancioneril se complementa con una nueva concepción del amor ${ }^{91}$; o viceversa: se diluye «a Petrarca en la maniera cancioneril», ya que «la pieza elaborada en un sistema entra en un código poético distinto» ${ }^{92}$, el del Cancionero general y aledaños. A pesar de que muchas veces sus autores se limiten a troquelar el sentido de los versos de Petrarca en un "vocabulario abstracto», a traducirlo en «estados emocionales y facultades de la mente» ${ }^{93}$. No se trata ya del Petrarca

antes de 1475, cuando Ortiz era familiar de Carrillo.

88. Ma Rosa Lida, «Una copla de Jorge Manrique y la tradición de Filón en la literatura española» [1942], ahora en Estudios sobre la Literatura Española del siglo XV, Madrid, José Porrúa Turanzas, 1977, pp. 145-178, 172.

89. María Morrás, ed. Jorge Manrique, Poesía, Madrid, Castalia, 2003, p. 22.

90. Vicente Beltrán, ed. cit, p. 16.

91. Como apuntaba tímidamente don Rafael Lapesa: «es innegable que, ya fuese por evolución espontánea, ya por infiltraciones claras o imperceptibles, se formó en la lírica de Castilla un clima poético afín al petrarquista» (La trayectoria poética de Garcilaso [1948], Madrid, Alianza, $1985^{2}$, p. 26); "el octosílabo, solo o en coplas de pie quebrado, se plegaba admirablemente... a la lozana vistosidad, a la o "sencilla fluidez o a la justeza conceptuosa", pero "no había la proyección alejadora, la marcha remansada, la suave tersura de Petrarca. Tal diferencia de orientación explica el que nuestra lírica del siglo XV tomara del petrarquismo algo del contenido, pero no la forma" (ibidem); también de don Rafael, "Poesía de cancionero y poesía italianizante"”, en De la Edad Media a nuestros días, Madrid, Gredos, 1967, pp. 145171. Complétese con J. Vinci, «The Petrarcan Source of Jorge Manrique’s Las Coplas», Italica, XLV (1968), pp. 314-326; Pedro Salinas, Jorge Manrique o tradición y originalidad, Seix Barral, Barcelona, 1974, pp. 73-78.

92. Francisco Rico, «De Garcilaso y otros petrarquismos», Revue de Littérature Comparée, LII (1978), pp. 325-338, 330-331; se refiere específicamente a Álvar Gómez y, en general, a la poesía de cancionero; también de F. Rico, «A fianco de Garcilaso: poesia italiana e poesia spagnola nel primo Cinquecento», Studi Petrarcheschi, IV (1987), pp. 229-236; Bienvenido Morros, "Manrique y Petrarca. Estudios del petrarquismo en la literatura del siglo XV», Medioevo Romanzo, XXIX (2005), pp. 132-156. En general, Keith Whinnom, La poesía amatoria de la época de los Reyes Católicos, Durham, Universidad, 1981.

93. Keith Whinnom, «Hacia una interpretación y apreciación de las canciones del 
vate que reivindicaba Santillana como conductor del verum poético, o sea, el Petrarca latino, regular y sucesivamente magnificado como auctoritas antonomástica ${ }^{94}$.

Pertinentemente, se tiende a abandonar «el estilo latinizante», a reivindicar el «baxo estilo», como Pero Guillén de Segovia, a la zaga de Mena, indica en el accessus a La gaya ciencia:

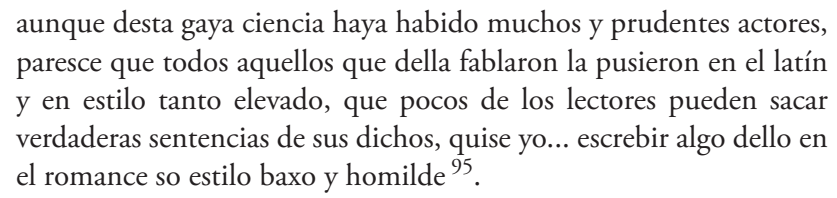

Es un estilo, concluye, pertinente con la poesía moral, eventualmente cultivada por las autoridades recientes, que, apunta, subrayaron el triumphus virtutis en sus mejores poemas; concretamente, la prudencia:

$$
\begin{aligned}
& \text { Bocacio con los modernos } \\
& \text { poetas de grand memoria } \\
& \text { por este viven en gloria. } \\
& \text {.... } \\
& \text { Aquésta puso al marqués } \\
& \text { bravecida diadema, } \\
& \text { y al de Mena cordobés, } \\
& \text { porque agora ni después } \\
& \text { perder su nombre no tema. } \\
& \text {.... } \\
& \text { Ya non falla quien se aplique } \\
& \text { a [iescalar?] su fuerte muro, } \\
& \text { do solo Gómez Manrique } \\
& \text { le place que comunique } \\
& \text { sus especias en lo puro } 96 .
\end{aligned}
$$

Se irá tendiendo a «la expresión llana y evocadora propia del sermo humilis», como vemos más tarde otros autores: así el jovencísimo Pedro de Cartagena (1456-1486), refiriéndose explícitamente a la Coplas contra los pecados mortales de Mena (no al Laberinto) como modelo de las suyas:

Cancionero general de 1511», Filología, XIII (1968-69), pp. 361-381, 366-367.

94. También moral, pues «erraríamos gravísimamente si ese 'laicismo' instrumental nos ocultara la decisiva huella que los padres imprimieron en Petrarca» (Francisco Rico, «Petrarca y las letras cristianas», Silva, I (2002), pp. 157-182, 171).

95. Cito por la edición de José Ma Casas Homs, Madrid, CSIC, 1962, 2 vols, I, p. 43.

96. Pero Guillén de Segovia, Obra poética, pp. 335-336. 
Va muy bien invencionado, va también digno de pena, porque salió del dechado que todos vimos labrado de mano de Juan de Mena ${ }^{97}$.

Más tarde lo defenderá Juan del Encina, que dejará que el lector note el contraste entre el manoseado arte mayor, formal y temáticamente, refiriéndose al mar griego, al principio de la Trivagia:

El cual poesía en gran precio aprecia, de ínsulas lleno que son veneradas con fábulas falsas, muy mucho estimadas, lo cual la Escritura Sagrada desprecia ${ }^{98}$,

y el arte real del «Romance y suma de todo el viaje», con un muy distinto final, sorpresivamente espontáneo:

Del archipiélago, parte nos cupo de pertransir, que de islas está lleno, que es peligro entre ella ir, de las cuales los poetas no poco suelen fingir. $Y$ por la isla pasamos de Cirigo o de Cetrir, do Paris robara a Elena, que fue a Troya un destruir.

Y fuemos cerca de Creta, que Candia suelen decir, do Saturno fue sepelido de Júpiter por regir.

y de Parenzo a Venecia fue el pasaje a concluir, de donde los peregrinos

97. Ana Ma Rodado Ruiz, ed., Pedro de Cartagena, Poesía, Cuenca, Universidad de Castilla-La Mancha, 2000, pp. 96-97.

98. Cito por la edición de Miguel Ángel Pérez Priego, Obra completa, Madrid, Turner (Biblioteca Castro), 1996, p. 422. Ricardo Senabre analiza los recursos del llamado 'arte real', subrayando especialmente «los artificios basados en la repetición..., que más que un rasgo de estilo es un principio constructivo» («oesía y poética de Juan del Encina», en Humanismo y literatura, pp. 205-216, 211-213). 
se tornaron a sparcir.

Yo me torné para Roma,

donde me place el vivir. (vv. 47-56, 435-438, 457-462)

Pocas veces se ha parodiado mejor el uso del saber clasicista que se hizo durante una parte del siglo XV, casi siempre enmarcado en la estética del arte mayor.

Con todo, Encina era consciente de la translatio, como recuerda en el prólogo a su traducción de las Bucólicas, no en balde dedicada a los Reyes Católicos, cuyo reinado se parangonó con la época dorada de la pax augusta cantada por Virgilio y Horacio ${ }^{99}$. También lo recordará Nebrija en el esbozo de las traslationes imperii et studii que figura en la dedicatoria a Isabel la Católica de la Gramática de la lengua castellana, donde pergeña el orto y ocaso de los imperios israelita, macedonio y romano para así llegar al triunfo de Castilla:

Los miembros e pedazos de España que estaban por muchas partes derramados se redujeron e ayuntaron en un cuerpo e unidad, la forma e trabazón del cual así está ordenada que muchos siglos, injurias e tiempos no la podrán romper ni desatar; así que, después de repurgada la cristiana religión..., después de los enemigos de nuestra fe vencidos por guerra e fuerza de armas..., después de la justicia e ejecución de las leyes que nos ayuntan e hacen vivir igualmente en esta gran compańía que llamamos reino e república de Castilla, no queda ya otra cosa sino que florezcan las artes de la paz ${ }^{100}$.

Encina la dedicaba a los reyes para justificar, precisamente, su «baxo estilo», que, no obstante, encierra una gran dignidad (consustancial con lo pastoril) y, lo más importante, está trufado de «altas sentencias» ${ }^{101}$, como también

99. Recuérdese, para abundar, que la égloga IV de Virgilio fue interpretada, digamos, mesiánicamente, pues "cantó in propria persona el futuro nacimiento de un nińo milagroso que inauguraría la última edad de las profecías sibilinas y un siglo dorado de paz universal»; una "profecía pagana divinamente inspirada por el Espíritu Santo, del nacimiento de Cristo» (Jeremy N. H. Lawrence, La tradición pastoril antes de 1530: imitación clásica e hibridación romancista en la Traslación de "Las Bucólicas» de Virgilio de Juan del Encina», en Humanismo y Literatura en tiempos de Juan del Encina, ed. J. Guijarro, Salamanca, Universidad, 1999, pp. 101-121, 103). Lo ratifica Encina: en el argumento de la Égloga cuarta, «aplicada al nacimiento bienaventurado» del príncipe Juan, de quien «manifiestamente parece Sibila profetizar... y Virgilio haber sentido de aqueste tan alto nacimiento, pues que después dél en nuestros tiempos habemos gozado de tan crecidas vitorias y triunfos»; se refiere al año 1478.

100. Cito por la edición de Francisco Rico, Felipe González Vega y Lourdes García Macho, Barcelona, Círculo de Lectores-CECE, en prensa.

101. Con todo, «el factor que distingue a Encina de los humanistas y traductores 
apuntaba arriba Pero Guillén. Lo confirma en el segundo prólogo (dedicado al príncipe Juan), donde justifica la polimetría en vez del hexámetro latino, pues la misma variedad métrica y el estilo rústico se emplean para captar la 'gracia' del estilo humilde de Virgilio:

Por no engendrar fastidio a los letores desta mi obra, acordé de la trobar en diversos géneros de metro y en estilo rústico, por consonar con el Poeta, que introduce personas pastoriles, aunque debaxo de aquella corteza y rústica simplicidad puso sentencias muy altas y alegóricos sentidos, y en esta obra se mostró no menos gracioso que doto en la Geórgica y grave en la Eneyda.

Es una reivindicación del sermo humilis agustiniano (De doctrina cristiana, IV), el de los textos sagrados, cuyo contenido doctrinal es perfectamente compatible con la humildad de la littera ${ }^{102}$. Aunque Encina también había podido haberlo comprobado en el Bucolicum carmen de Petrarca, donde alude a la esencia alegórica de la pastoral ${ }^{103}$.

anteriores del siglo XV... es la manera original en que aborda la tarea de combinar la imitación erudita de un determinado autor de la Antigüedad con su translatio o transferencia a la lengua romance»; «se trata más de un intento de imitatio clásica que de una traducción incompetente» (Lawrance, «La tradición pastoril», pp. 113 y 115). Cf. Lore Terracini, Lingua come problema nella letteratura spagnola del Cinquecento (con una frangia cervantina), Turín, Stampatori, 1979; Avelina Carrera de la Red, El «problema de la lengua» en el Humanismo renacentista español, Valladolid, Universidad de Valladolid-Caja de Ahorros de Salamanca, 1988; Pedro Ruiz Pérez, «La cuestión de la lengua castellana: aspectos literarios y estéticos en los siglos XV y XVI», en Gramática y humanismo, ed. P. Ruiz Pérez, Córdoba, LibertariasAyuntamiento de Córdoba, 1993, pp. 119-143; Luis Fernández Gallardo, «Latín y vulgar. Ideas sobre la lengua en la Castilla del siglo XV», Revista de Poética Medieval, VIII (2002), pp. 11-76; mi artículo "La defensa de la lengua natural entre los primeros humanistas", Ínsula, núms. 691-692 (2004), pp. 8-11. Compárese con Domingo Ynduráin, «La invención de una lengua clásica», Edad de Oro, I (1982), pp. 13-34.

102. Daniela Capra, "Encina frente a los clásicos (con un escorzo agustiniano», en Humanismo y literatura, pp. 317-324. Complétese con Margherita Morreale, «Fray Luis de León y Juan del Encina ante la 10a égloga de Virgilio», en Fray Luis de León. Aproximaciones a su vida y su obra, eds. C. Morón y M. Revuelta, Santander, Sociedad Menéndez Pelayo, 1989, pp. 231-280. Véanse también Concepción Salinas, «Antiguos y modernos en el Arte de poesía castellana de Juan del Encina», en Humanismo y literatura en tiempos de Juan del Encina, ed. J. Guijarro, Salamanca, Universidad, 1999, pp. 431-438; Domingo Ynduráin, "Juan del Encina y el humanismo», en Humanismo y literatura, pp. 259-280.

103. Véase de nuevo J. N. H. Lawrance, «La tradición pastoril», pp. 108-112; más abajo vincula la traslación de Encina con la lectura de las Coplas de Mingo Revulgo y con la Batalla campal de los perros contra los lobos (1457), de Alfonso de Palencia. También tendría en cuenta el diagrama de la Rota Virgilii, que difundió especialmente Juan de Garlandia; cf. Edmond Faral, Les Arts poétiques du XII et $d u X I I I^{e}$ siècle: recherches et documents sur la technique littéraire du Moyen Age, Paris, Champion, 1924, p. 87. 
Una vez difundida la cultura antigua por la generación anterior, que Diego de Burgos personalizaba en Santillana, Encina marca la segunda y definitiva fase de la translatio studii, tomando como modelo a su maestro Nebrija:

según dice el dotísimo maestro Antonio de Lebrija... una de las causas que le movieron a hacer arte de romance fue que creía nuestra lengua estar agora más empinada y polida que jamás estuvo..., así yo por esta mesma razón, creyendo haber estado tan puesta en la cumbre nuestra poesía y manera de trovar, pareciome ser cosa muy provechosa ponerla en arte..., porque ninguna antigüedad de tiempos le pueda traer olvido... Así que concluyamos luego el trovar haber cobrado sus fuerzas en Italia y de allí esparcídolas por nuestra España, adonde creo yo florece más que en ninguna otra parte ${ }^{104}$.

De estas palabras se induce que está convencido de la traslación de la auctoritas a los modernos y la dignificación de la poesía castellana, que ha hecho entroncar con los clásicos, trazando una genealogía que va de los poetas latinos a los contemporáneos, sin mencionar a los provenzales. ${ }^{105}$ Esta omisión no es menos significativa que la solapada defensa de la poesía «moderna», la que ha vuelto a la intensa brevedad del arte real, al sermo humilis:

Otras muchas más figuras y licencias pudiéramos contar, mas porque los modernos gozan de la brevedad, contentémonos con éstas, las cuales no debemos usar muy a menudo, pues que la necesidad principalmente fue causa de su invención..., especialmente de cuatro o cinco principales debemos hacer fiesta [encadenado, retrocado, redoblado, multiplicado, reiterado]..., mas no las debemos usar muy a menudo, que el guisado con mucha miel no es bueno sin algún sabor de vinagre. (pp. 91-92)

Las galas que recomienda Encina son las mismas que definen el conceptismo manriqueño y alrededores, a partir de 1475 , lejos ya de los hipérbatos del arte mayor; de su falsa y mal asimilada ejemplaridad paganizante ${ }^{106}$, que ya

104. Edición de F. López Estrada, pp. 78 y 82.

105. Cf. J. Richard Andrews, Juan del Encina. Prometheus in Search of Prestige, BerkeleyLos Ángeles, University of California Press, 1959, pp. 73 y 76; Julian Weiss, The Poet's Art, p. 237; Concepción Salinas, «Antiguos y modernos en el Arte de poesía castellana de Juan del Encina", en Humanismo y literatura, pp. 431-438, 437.

106. Incluso la de la invocación inicial a los dioses o las musas, que se hace, «no porque creamos como ellos [los antiguos] ni los tengamos como por dioses invocándolos..., mas por seguir su gala y orden poética, que es haber de proponer, invocar y narrar o contar las ficiones graves y arduas, de tal manera que, siendo fición la obra, es mucha razón que no menos sea 
aborreció Mena en su última época; de las extravagancias latinizantes; de los autores clásicos de menor relieve "moral»; de la tiranía del ictus, etc., etc. Pero, a su vez, con una lengua muy parecida a la hablada, con imágenes muy concretas, que la alejan de la primera poesía cancioneril, donde el amor, los temas morales e incluso teológicos estaban lastrados por un alto grado de abstracción y adecuados a las disputationes escolásticas.

El nuevo canon, el Parnaso después de Santillana y Mena, lo presidía Jorge Manrique, pues ni Pero Guillén ni Gómez Manrique, supuestos y respectivos relevos de Mena y Santillana, renovaron la poesía del Cuatrocientos castellano. Y Encina certificaba la nueva época, la translatio studii que señalaba su maestro Nebrija, y el relevo moral y estético de Jorge Manrique, en cuyas Coplas introduce una nota concreta, plástica o emotiva, un componente evocador de gran eficacia sentimental -más cercano de lo que se conocerá como petrarquismo-, subrayada con un ritmo adecuado, cuya sincera naturalidad y sentida gravedad de los argumentos filosóficos, históricos, morales y teológicos hacen que el lector se implique emocionalmente en la elegía ${ }^{107}$, porque, precisamente, se aleja en gran medida de las abstracciones cancioneriles y de las auctoritates de oropel: él mismo es autoridad, la autoridad.

\footnotetext{
fingida y no verdadera la invocación della» (p. 79).

107. «Las Coplas consiguen hacernos asentir a cuanto nos proponen, porque lo dicen con el ritmo de una prodigiosa naturalidad, tan gentilmente rotunda, que parece sin réplica posible, y porque transportan cuanto tocan a un orden de perfección estética absoluta y sin embargo cercana» (Francisco Rico, «La tradición, el poema», p. 289).
} 


\section{BibliografíA}

Andrews, J. Richard, Juan del Encina. Prometheus in Search of Prestige, Berkeley-Los Ángeles, University of California Press, 1959, pp. 73 y 76.

Atalaya, VII (1996) = L'humanisme en Espagne au XV' siècle.

Avenoza, Gemma, «Lope García de Salazar: La formación de un bibliófilo y de su biblioteca, una visión general», eHumanista, VI (2006), pp. 34-67.

BADIA, Lola, «L'humanisme català: formació i crisi d'un concepte historigràfic», en De Bernat Metge a Joan Rois de Corella, Barcelona, Quaderns Crema, 1988, pp. 13-38.

- Tradició i modernitat als segles XIV i XV, Valencia-Barcelona, Institut Universitari de Filologia Valenciana-Abadia de Montserrat, 1993.

- «La legitimació del discurs literari en vulgar segons Ferran Valentí», en Intel.lectuals i escriptors a la baixa Edat Mitjana, eds. L. Badia y A. Soler, Barcelona, CurialAbadia de Montserrat, 1994, pp. 161-184.

Baldissera, Andrea, ed., Alonso de Cartagena, Por Marcelo, Lucca, Agua y Peña, 2003.

Beltrán, Vicente, ed., Jorge Manrique, Poesía, Barcelona, Crítica, 1993.

Billanovich, Giuseppe, Auctorista, humanista, orator, Bellaterra, Universidad Autónoma de Barcelona, 1989.

Binotti, Lucia, «La Epístola exhortatoria a las letras de Juan de Lucena. Humanismo y educación en la Castilla del siglo XV», La Corónica, XXVIII (2000), pp. 5180.

Blecua, Alberto, "Virgilio en España en los siglos XVI y XVII», en Actes del VI Simposi. d'Estudis Clàssics, Bellaterra, Secció Catalana de la Societat Espanyola d'Estudis Clàssics-Universidad Autónoma de Barcelona, 1985, pp. 61-77.

BlüHer, Karl A., Séneca en España, Madrid, Gredos, 1983.

Bouwsma, William J., A Usable Past. Essays in European Cultural History, Berkeley, University of California Press, 1990.

ButiñÁ, Julia, "Algunas consideraciones sobre poética medieval en el humanismo catalán: Bernat Metge y el Curial e Güelfa», Revista de Poética Medieval, XII (2004), pp. 11-52.

Cancionero castellano del siglo XV, ed. R. Foulché Delbosc, 2 vols., Madrid, BAE, 1912.

Cangiotti, Gualterio, Le "Coplas» di Manrique tra Medioevo e Umanesimo, Riccardo Pàtron, Bolonia, 1964.

Cappelli, Guido, El humanismo romance de Juan de Lucena. Estudios sobre el «De vita felici», Bellaterra, Universidad Autónoma de Barcelona, 2002.

CAPra, Daniela, «Encina frente a los clásicos (con un escorzo agustiniano)», en Humanismo y literatura, pp. 317-324.

CARrera de la Red, Avelina, El «problema de la lengua» en el Humanismo renacentista español, Valladolid, Universidad de Valladolid-Caja de Ahorros de Salamanca, 1988. 
Casas Homs, José Ma ed., Pero Guillén de Segovia, La gaya ciencia, Madrid CSIC, 1962, 2 vols

Casas Rigall, Juan, "La idea de agudeza en el siglo XV hispano: para una caracterización de la sotileza cancioneril», Revista de Literatura Medieval, VI (1994), pp. 79-103.

Cátedra, Pedro M., ed., Enrique de Villena, Traducción y glosas a la "Eneida». (Libros I-III), 3 vols., Salamanca, Biblioteca Española del Siglo XV-Diputación Provincial, 1989-1990.

- «Un aspecto de la difusión del escrito en la Edad Media: la autotraducción al romance», Atalaya, 2 (1991), pp. 67-84.

- «El sentido involucrado y la poesía del siglo XV. Lecturas virgilianas de Santillana con Villena», en "Nunca fue pena mayor». Estudio de literatura española en homenaje a Brian Dutton, eds. A. Menéndez Collera y V. Roncero, Cuenca, Universidad de Castilla-La Mancha, 1996, pp. 149-161.

- ed., Tratados de amor en el entorno de "Celestina" (siglos XV-XVI), Madrid, Sociedad Estatal España Nuevo Milenio, 2001.

Cherchi, Paolo, «Pero Díaz de Toledo y su Diálogo e razonamiento en la muerte del marqués de Santillana», en Historias y ficciones, eds. R. Beltrán, J. L. Canet y J. L. Sirera, Valencia, Universidad, 1992, pp. 111-120.

Conde, Juan Carlos, «El siglo XV castellano a la luz del Diálogo de vita beata de Juan de Lucena», Dicenda, IV (1985), pp. 11-34.

Crosas lópez, Francisco, La materia clásica en la poesía de cancionero, Kassel, Reichenberger, 1995.

- «De Diis Gentium». Tradición clásica y cultura medieval, Nueva York, Peter Lang, 1998.

Cummins, John G., "Pero Guillén de Segovia y el Ms. 4114», Hispanic Review, XLI (1973), pp. 6-32.

- ed., Juan de Mena, Laberinto de Fortuna, Madrid, Cátedra, 1982.

De Nigris, Carla, ed., Juan de Mena, "Laberinto de Fortuna» y otros poemas, Barcelona, Crítica, 1994.

Delgado León, Feliciano, "La coronación» de Juan de Mena, Córdoba, Caja de Ahorros, 1978.

Di Camillo, Ottavio, El Humanismo castellano del siglo XV, Valencia, Fernando Torres, 1976.

- "Humanism in Spain», en Renaissance Humanism. Foundations, Forms and Legacy, Filadelfia, University of Pennsylvania Press, 1988, II, pp. 55-108.

- «Interpretations of the Renaissance in Spanish Historical Thought», Renaissance Quarterly, XLVIII (1995), pp. 352-365.

- "Interpretations of the Renaissance in Spanish Historical Thought: The Last Thirty Years», Renaissance Quarterly, XLIX (1996), pp. 360-383.

- «Interpretations of Humanism in Recent Spanish Renaissance Studies», Renaissance Quarterly, L (1997), pp. 1190-1201. 
Díez Garretas, María Jesús, ed., La obra literaria de Fernando de la Torre, Valladolid, Universidad, 1983.

- y Ma Wenceslada de Diego Lobejón, Un cancionero para Álvar García de Santamaría. "Diversas virtudes y vicios» de Fernán Pérez de Guzmán, Tordesillas, Universidad de Valladolid, 2000.

Domínguez, César, El concepto de «materia» en la teoría literaria del Medioevo, Madrid, CSIC, 2004.

Elia, Paola, ed., Fernando del Pulgar, Letras, Pisa, Giardini, 1982.

Encina, Juan del, Obra completa, ed. Miguel Ángel Pérez Priego, Madrid, Turner (Biblioteca Castro), 1996.

FARAL, Edmond, Les Arts poétiques du XII et du XIII siècle: recherches et documents sur la technique littéraire du Moyen Âge, Paris, Champion, 1924.

Fernández Gallardo, Luis, "Tradición clásica, política y humanismo en la Castilla del Cuatrocientos. Las glosas de Alonso de Cartagena a De providentia», Anuario de Estudios Medievales, XXIV (1994), pp. 967-1002.

- «Latín y vulgar. Ideas sobre la lengua en la Castilla del siglo XV», Revista de Poética Medieval, VIII (2002), pp. 11-76.

Fernández López, Sergio, Lecturas hebraizantes del "Cantar de los cantares» en la literatura española. De la Edad Media al Humanismo, tesis doctoral inédita de la Universidad de Huelva, 2007.

Ferrie, Francis, «Aspiraciones del humanismo español del siglo XV. Revalorización del Proemio e carta de Santillana», RFE, LVII (1974-75), pp. 195-209.

Folger, Robert, 'Generaciones y semblanzas': Memory and Genealogy in Medieval Iberian Historiography. Romanica Monacensia 68. Tübingen: Gunter Narr, 2003.

ForRADELlas, Joaquín, "Aproximación a la lectura del Decir a las syete virtudes», en Juan Alfonso de Baena y su "Cancionero", eds. J. L. Serrano Reyes y J. Fernández Jiménez, Baena, Diputación Provincial de Córdoba, 2001, pp. 153-160.

Gir, Luis, Reseña de Ángel Gómez Moreno, España y la Italia de los humanistas. Primeros ecos, Madrid, Gredos, 1994, Romance Philology, LI (1998), pp. 522532.

Gómez Moreno, Ángel, «La Qüestión del marqués de Santillana a don Alfonso de Cartagena», El Crotalón, II (1985), pp. 335-363.

- El «Prohemio e carta» del marqués de Santillana y la teoría literaria del siglo XV, Barcelona, PPU, 1990.

- España y la Italia de los humanistas. Primeros ecos, Madrid, Gredos, 1994.

- «La militia clásica y la caballería medieval: las lecturas de re militari entre Medioevo y Renacimiento", Evphrosyne, XXIII (1995), pp. 83-97.

- ed., Sexto Julio Frontino, Los cuatro libros de los Enxemplos, consejos e avisos de la guerra (Strategematon), Madrid, Ministerio de Defensa, 2005.

Gómez Redondo, Fernando, Artes poéticas medievales, Madrid, Laberinto, 2000.

Holtz, Louis, "Glosse e commenti», en Lo spazio letterario del Medioevo. 1. Il 
Medioevo Latino, III: La ricezione del testo, eds. G. Cavallo, C. Leornari y E. Menestò, Roma, Salerno, 1995, pp. 59-111.

Humanismo y literatura = Humanismo y literatura en tiempos de Juan del Encina, ed. J. Guijarro, Salamanca, Universidad, 1999.

Humanismo y pervivencia $=$ Humanismo y pervivencia del mundo clásico, ed. J. Ma Maestre Maestre y J. Pascual Barea, Cádiz, Instituto de Estudios TurolensesUniversidad de Cádiz, 1993, 2 vols.

Humanismo y Renacimiento = Actas del Congreso Internacional sobre Humanismo y Renacimiento, ed. J. Matas, León, Universidad, 1998, 2 vols.

Impey, Olga T., "Alfonso de Cartagena, traductor de Séneca y precursor del humanismo español», Prohemio, III (1972), pp. 473-494.

- «Ovid, Alfonso X, and Juan Rodríguez del Padrón: Two Castilian Translations of the Heroidas and the Beginings of Spanish Sentimental Prose», Bulletin of Hispanic Studies, 57 (1980), pp. 283-297.

Joset, Jacques, «Sueños y visiones medievales: razones de sinrazones», Atalaya, VI (1995), pp. 51-70.

LAPESA, Rafael, La trayectoria poética de Garcilaso [1948], Madrid, Alianza Editorial, $1985^{2}$.

- «Poesía de cancionero y poesía italianizante», en De la Edad Media a nuestros dias, Madrid, Gredos, 1967, pp. 145-171.

- «Poesía docta y afectividad en Gómez Manrique», en De Ayala a Ayala, Madrid, Istmo, 1988, pp. 55-64.

Lawrance, Jeremy N. H., Un tratado de Alonso Cartagena sobre la educación y los estudios literarios, Bellaterra, Universidad Autónoma de Barcelona, 1979.

- «On the Fifteenth-Century Spanish Vernacular Humanism», en Medieval and Renaissance Studies in Honour of Brian Tate, eds. I. Michael y R. A. Cardwell, Oxford, Dolphin, 1986, pp. 63-79.

- «Nuevos lectores y nuevos géneros: apuntes y observaciones sobre la epistolografía en el primer renacimiento español», en Literatura en la época del Emperador. Academia Literaria Renacentista V, ed. V. García de la Concha, Salamanca, Universidad, 1988, pp. 81-99.

- Un episodio del proto-humanismo español. Tres opúsculos de Nuño de Guzmán y Giannozzo Manetti, Salamanca, Biblioteca Española del Siglo XV, 1989.

- «La traduction espagnole du De libris gentilium legendis de Saint Basile, dédiée au Marquis de Santillane», Atalaya, I (1991), pp. 81-115.

- «La autoridad de la letra: un aspecto de la lucha entre humanistas y escolásticos en la Castilla del siglo XV», en Écrits et lectures au Moyen Âge, Atalaya, II (1991), pp. 85-105.

- «La tradición pastoril antes de 1530: imitación clásica e hibridación romancista en la Traslación de "Las Bucólicas» de Virgilio de Juan del Encina», en Humanismo y Literatura, pp. 101-121.

LÁzaro Carreter, Fernando, «La poética del arte mayor castellano» [1972], en sus Estudios de poética (la obra en sí), Madrid, Taurus, 1976, pp. 75-111. 
Le Gentil, Pierre, La Poésie lyrique espagnole et portugaise à la fin du Moyen Âge, I, Les Thèmes et les genres, Rennes, Philon, 1949.

Lida, Ma Rosa, Juan de Mena, poeta del Prerrenacimiento español [1950], México, El Colegio de México, $1984^{2}$.

- «La General estoria: notas literarias y filológicas», Romance Philology, XII (195859), pp. 111-142; XIII (1959-60), pp. 1-30.

- Estudios sobre la Literatura Española del siglo XV, Madrid, José Porrúa Turanzas, 1977.

López Bascuñana, Ma Isabel, «El mundo y la cultura grecorromana en la obra del marqués de Santillana», Revista de Archivos, Bibliotecas y Museos, LXXX (1977), pp. 271-320.

López Estrada, Francisco, Las poéticas castellanas de la Edad Media, Madrid, Taurus, 1984.

Lucena, Juan de, Libro de vita beata (1463), ed. A. Paz y Melia, en Opúsculos literarios de los siglos XIV a XVI, Madrid, BAE, 1892.

Marimón Llorca, Carmen, "Las claves retóricas del discurso poético en el Medioevo: la tópica horaciana mayor», Revista de Poética Medieval, VIII (2002), pp. 111-143.

Martín Fernández, Ma Amor, Juan de Mena y el Renacimiento. Estudio de la mitología en su obra menor, Córdoba, Caja de Ahorros, 1985.

Menéndez Pelayo, Marcelino, Historia de las ideas estéticas en España [1883], Madrid, CSIC, 1994, 2 vols.

- Orígenes de la novela [1905-1915], Santander, Edición Nacional, 1962, 4 vols. - Antología de poetas líricos castellanos, Madrid, CSIC, 1944.

Miguel-Prendes, Sol, "Translation, Authority, and Authorship in the Works of Enrique de Villena and Juan de Mena: The Emergence of the Vernacular Author in Fifteenth-Century Castile», Allegorica, 6 (1996), pp. 17-33.

- El espejo y el piélago. La "Eneida» castellana de Enrique de Villena, Kassel, Reichenberger, 1998.

Minnis, Alistair J., Medieval theory of authorship, Londres, Wildwood House, $1988^{2}$.

Mora-Lebrun, Francine, $L$ ' «néide» médiévale et la naissance du roman, Paris, PUF, 1994.

Moreno Hernández, Carlos, «Pero Guillén de Segovia y el círculo de Alfonso de Carrillo", Revista de Literatura, XLVII (1985), pp. 17-49.

- ed., Pero Guillén de Segovia, Obra poética, Madrid, FUE, 1989.

Morrás, María, «Un tópico ciceroniano en el debate sobre las armas y las letras», en Actas del IV Congreso de la AHLM, Lisboa, Cosmos, 1993, IV, pp. 115-122.

- «Sic et non. En torno a Alfonso de Cartagena y los studia humanitatis», Evphrosyne, XXIII (1995), pp. 333-346.

- ed., Alonso de Cartagena, Libros de Tulio: "De senectute», "De los ofiçios», Alcalá de Henares, Universidad, 1996. 
- «Una cuestión disputada: viejas y nuevas formas en el siglo XV. A propósito de un opúsculo inédito de Rodrigo Sánchez de Arévalo y Alfonso de Cartagena", Atalaya, VII (1996), pp. 63-102.

- «El debate entre Leonardo Bruni y Alonso de Cartagena: las razones de una polémica», Quaderns. Revista de Traducció, VII (2002), pp. 33-57.

- ed. , Jorge Manrique, Poesía, Madrid, Castalia, 2003.

Morreale, Margherita, "El Decir a las siete virtudes de Francisco Imperial. Lectura e imitación renacentista de la Divina Comedia», en Estudios dedicados a Rodolfo Oroz, Santiago de Chile, 1967, pp. 307-367.

- «Fray Luis de León y Juan del Encina ante la 10a égloga de Virgilio», en Fray Luis de León. Aproximaciones a su vida y su obra, eds. C. Morón y M. Revuelta, Santander, Sociedad Menéndez Pelayo, 1989, pp. 231-280.

Morros, Bienvenido, "Manrique y Petrarca. Estudios del petrarquismo en la literatura del siglo XV», Medioevo Romanzo, XXIX (2005), pp. 132-156.

Nebrija, Antonio de, Gramática de la lengua castellana, eds. Francisco Rico, Felipe González Vega y Lourdes García Macho, Barcelona, Círculo de Lectores-CECE, en prensa.

Nebrija y la Introducción = Nebrija y la Introducción del Renacimiento en España. Actas de la III Academia Literaria Renacentista, ed. V. García de la Concha, Salamanca, Universidad, 1983.

Nepaulsingh, Colbert I., ed., Francisco Imperial, «El Dezir a las syete virtudes» y otros poemas, Madrid, Espasa-Calpe, 1977.

Parrilla, Carmen, "Qui scit, docere debet'. Acerca de Alfonso de Madrigal el Tostado», Archivum, LIV-LV (2004-2005), pp. 367-390.

Pérez Priego, Miguel Ángel, „El 'Claro Escuro' de Juan de Mena», en El comentario de textos, 4. La poesía medieval, Madrid, Castalia, 1983, pp. 427-449.

- ed., Juan de Mena, Obras completas, Barcelona, Planeta, 1989.

Perotti, Olga, ed., Juan de Lucena, De vita felici, Pavia, Ibis, 2004.

Perugini, Carla, ed., Questión de amor, Salamanca, Universidad, 1995.

Pontón, Gonzalo, Correspondencias. Los orígenes del arte epistolar en España, Madrid, Biblioteca Nueva, 2002.

Quilliet, Bernard, La tradition humaniste, Paris, Fayard, 1981.

Regoliosi, Mariangela, «Riflessioni umanistiche sullo scrivere storia», Rinascimento, XXXI (1991), pp. 3-37.

Rico, Francisco, Vida u obra de Petrarca. I. Lectura del «Secretum», Padua-Chapel Hill, University of North Carolina, 1974.

- Nebrija frente a los bárbaros, Salamanca, Universidad, 1978.

- ed., Francisco Petrarca, Obras, I, Madrid, Alfaguara, 1978.

- "De Garcilaso y otros petrarquismos», Revue de Littérature Comparée, LII (1978), pp. 325-338.

- «A fianco de Gracilaso: poesia italiana e poesia spagnola nel primo Cinquecento", Studi Petrarcheschi, IV (1987), pp. 229-236.

- «Unas coplas de Jorge Manrique y las fiestas de Valladolid en 1428», AEM, 


\section{LA AUTORIDAD LITERARIA}

II (1965), pp. 515-424; reeditado en Textos y contextos. Estudios sobre la poesía española del siglo XV, Barcelona, Crítica, 1990, pp. 169-187.

- "Aristóteles Hispanus: en torno a Gil de Zamora, Petrarca y Juan de Mena», Italia Medioevale e Umanistica, X (1967), pp. 143-164; reeditado en Textos y contextos, pp. 55-94.

- «Temas y problemas del Renacimiento español», en Historia y Crítica de la Literatura Española. Siglos de Oro: Renacimiento, Barcelona, Crítica, 1980, pp. 1-27.

- «Un prólogo al Renacimiento español. La dedicatoria de Nebrija en las Introductiones latinae (1488)", en Seis lecciones sobre la España de los Siglos de Oro. Homenaje a M. Bataillon, eds. P. Piñero y R. Reyes Cano, Sevilla, Universidad, 1981, pp. 59-94.

- «Lección y herencia de Elio Antonio de Nebrija», en Nebrija en Cataluña, eds.

F. Rico y A. Soberanas, Barcelona, Biblioteca de Catalunya, 1981, pp. 3-15.

- «Petrarca y el 'humanismo catalán'», en Actes del Sisè Col.loqui Internacional de Llengua i Literatura Catalanes, eds. G. Tavani y J. Pinell, Barcelona, Publicacions de l'Abadía de Montserrat, 1982, pp. 257-291.

- "Philology and Philosophy in Petrarch", en Intellectuals and Writers in Fourteenth-Century Europe, eds. P. Boitiani y A. Torti, Tubinga-Cambridge, Gunter Narr-D. S. Brewer, 1986, pp. 45-66.

- "La tradición, el poema», en Breve biblioteca de autores españoles, Barcelona, Seix Barral, 1990, pp. 286-293.

- «La realidad y el estilo (el humanismo de La Celestina)», estudio preliminar a Fernando de Rojas (y «antiguo autor»), La Celestina, ed. de F. Lobera, G. Serés, P. Díaz-Mas, C. Mota e Í Ruiz Arzálluz, y F. Rico, Barcelona, Crítica, 2001, pp. XV-XLVII.

- «Petrarca y las letras cristianas», Silva, I (2002), pp. 157-182.

- El sueño del humanismo. De Petrarca a Erasmo, [1993], Barcelona, Destino, $2002^{2}$.

Rodado Ruiz, Ana Ma, ed., Pedro de Cartagena, Poesía, Cuenca, Universidad de Castilla-La Mancha, 2000.

Rodríguez Velasco, Jesús, El debate sobre la caballería en el siglo XV, Salamanca, Junta de Castilla y León, 1996.

- «La Biblioteca y los márgenes. Ensayo teórico sobre la glosa en el ámbito cortesano del siglo XV en Castilla. I: códice, dialéctica y autoridad», Ehumanista. Journal of Iberian Studies, 1 (2001), pp. 119-134.

Rohland de Langbehn, Regula, ed., Marqués de Santillana, Comedieta de Ponza, sonetos, serranillas y otras obras, estudio preliminar de Vicente Beltrán, Barcelona, Crítica, 1997.

Rossi, Paolo, Clavis universalis, Millon, Grenoble, 1993.

Round, Nicholas G., "The Shadow of a Philosopher: Medieval Castilian Image of Plato», Journal of Hispanic Philology, III (1978), pp. 187-227. 
- Libro llamado "Fedrón». Plato's "Phaedro" Translated by Pero Díaz de Toledo, Londres-Madrid, Tamesis, 1993.

- "Perdóneme Séneca'. The Translational Practices of Alonso de Cartagena», Bulletin of Hispanic Studies [Glasgow], LXXV (1998), pp. 17-29.

Ruiz PÉrez, Pedro, «La cuestión de la lengua castellana: aspectos literarios y estéticos en los siglos XV y XVI», en Gramática y humanismo, ed. P. Ruiz Pérez, Córdoba, Libertarias-Ayuntamiento de Córdoba, 1993, pp. 119-143.

Salinas, Concepción, "Antiguos y modernos en el Arte de poesía castellana de Juan del Encina», en Humanismo y literatura, pp. 431-438.

Salinas, Pedro, Jorge Manrique o tradición y originalidad, Seix Barral, Barcelona, 1974.

Schiaffini, Alfredo, "Poesis e poeta in Dante», en Studia philologica et litteraria in honorem Leo Spitzer, eds. A. G. Hatcher y K. L. Selig, Berna, Francke, 1958, pp. 379-389.

Schiff, Mario, La Bibliothèque du Marquis de Santillane, París, E. Bouillon, 1905 (reimpresión: Amsterdam, G. Th. van Heuden, 1970).

Scholberg, Kenneth, Introducción a la poesía de Gómez Manrique, Madison, Wisconsin University Press, 1984.

Senabre, Ricardo, "Poesía y poética de Juan del Encina», en Humanismo y literatura, pp. 205-216.

SerÉs, Guillermo, «Ficción sentimental y humanismo: La Sátira de don Pedro de Portugal», Bulletin Hispanique, XCIII (1991), pp. 31-60.

- "Juan de Mena y el 'Prerrenacimiento'", introducción a Juan de Mena, Laberinto de fortuna y otros poemas, estudio preliminar, ed. de Carla de Nigris, Barcelona, Crítica, 1994, pp. IX-XXXII.

- «La elegía de Juan Rodríguez del Padrón», Hispanic Review, LXII (1994), pp. 1-22.

- La traducción en Italia y España durante el siglo XV. La "Iliada» en romance y su contexto cultural, Salamanca, Universidad, 1997.

- "Una nota sobre el escolasticismo poético en el otoño de la Edad Media», Scriptura, XIII (1997), pp. 19-31.

- «La ficción y la 'verdad del entendimiento': algunas consideraciones de poética medieval», Revista de Poética Medieval, IV (2000), pp. 153-186.

- «El evemerismo medieval espańol: de Alfonso el Sabio al Tostado», en La razón del mito. I Congreso de mitología mediterránea, coord. G. Luri, Madrid, UNED, 2000, pp. 159-175.

- «La defensa de la lengua natural entre los primeros humanistas», Insula, núms. 691-692 (2004), pp. 8-11.

- «La poética de Petrarca y el Prehumanismo castellano del siglo XV», Evphrosyne. Revista de Filologia Clássica, XXXIII (2005), pp. 85-107.

Serrano de Haro, Antonio, Personalidad y destino de Jorge Manrique [1966], Madrid, Gredos, $1975^{2}$.

Serverat, Vincent, «Le Laberinto de Fortuna de Juan de Mena ou le crépuscule du 
dit médiéval», en La poésie castillane de la fin du Moyen Âge au début du Siècle d'Or, coord. J. Battesti Pelegrin, Paris, Editions du Temps, 1997, pp. 11-35.

Sottili, Agostino, Giacomo Publicio, "Hispanus» e la diffusione dell'Umanesimo in Germania, Universidad Autónoma de Barcelona, Bellaterra, 1985.

TATE, Robert B., "The Civic Humanism of Alfonso de Palencia", Renaissance and Modern Studies, XXIII (1979), pp. 25-44.

- "Alfonso de Palencia y los preceptos de la historiografía», en Nebrija y la introducción, pp. 37-51.

- «El humanismo en Andalucía en el siglo XV», en Andalucía 1492: razones de un protagonismo, eds. C. de Terán Sánchez et al., Sevilla, Algaida, 1992, pp. 213-241.

- y R. Alemany, ed., Alfonso de Palencia, Epistolas latinas, Bellaterra, Universidad Autónoma de Barcelona, 1982, pp. 7-25.

Terracini, Lore, Lingua come problema nella letteratura spagnola del Cinquecento (con una frangia cervantina), Turín, Stampatori, 1979.

Vidal González, Francisco, ed., Gómez Manrique, Cancionero, Madrid, Cátedra, 2003.

VINCI, Joseph, «The Petrarcan Source of Jorge Manrique’s Las Coplas», Italica, XLV (1968), pp. 314-326.

Viña Liste, José María, ed., Alonso de Cartagena, Doctrinal de los caballeros, Santiago de Compostela, Universidad, 1995.

VITI, P., "Leonardo Bruni e le polemiche antiumanistiche», en Gli umanesimi medievali. Atti del II Congresso dell' Internationales Mittelalteinerkomitee", ed. C. Leonardi, Florencia, Universidad, 1998, pp. 795-805.

Weiss, Julian, The Poet's Art. Literary Theory in Castile, c. 1400-60, Oxford, The Society for the Study of Medieval Languages ands Literature, 1990.

- «Tiempo y materia en la poética de Juan del Encina», en Humanismo y literatura, pp. 241-257.

- «Political Commentary: Hernán Núñez’s Glosa a Las Trescientas», en Letters and Society in Fifteenth-Century Spain. Studies presented to P. E. Russell on his eightieth birthday, pp. 205-216.

Whinnom, Keith, «Hacia una interpretación y apreciación de las canciones del Cancionero general de 1511», Filología, XIII (1968-69), pp. 361-381.

- La poesía amatoria de la época de los Reyes Católicos, Durham, Universidad, 1981.

Wiтt, Ronald G., "Medieval ars dictaminis and the Beginnings of Humanism: A new Construction of the Problem», Renaissance Quarterly, XXXV (1982), pp. 1-35.

Wittlin, Curt J., ed., Pero López de Ayala, Las Décadas de Tito Livio. Edición crítica de los libros I-III. Barcelona, Puvill, 1982, 2 vols.

Ynduráin, Domingo, «La invención de una lengua clásica», Edad de Oro, I (1982), pp. 13-34.

- Humanismo y Renacimiento en España, Madrid, Cátedra, 1994.

- «Juan del Encina y el humanismo», en Humanismo y literatura, pp. 259-280. 
